Article

\title{
Effect of Rhododendron arboreum Leaf Extract on the Antioxidant Defense System against Chromium (VI) Stress in Vigna radiata Plants
}

\author{
Vandana Gautam ${ }^{1}$, Pooja Sharma ${ }^{1}$, Palak Bakshi ${ }^{1}$, Saroj Arora ${ }^{1}$, Renu Bhardwaj ${ }^{1}$, \\ Bilal Ahmad Paray ${ }^{2}$, Mohammed Nasser Alyemeni ${ }^{3}$ and Parvaiz Ahmad ${ }^{3,4, *(\text { C) }}$ \\ 1 Department of Botanical and Environmental Sciences, Guru Nanak Dev University, Amritsar 143005, India; \\ vndu.gndu@gmail.com (V.G.); pooja.sharma@gmail.com (P.S.); p.bakshi@gmail.com (P.B.); \\ sarojarora.gndu@gmail.com (S.A.); renubhardwaj82@gmail.com (R.B.) \\ 2 Zoology Department, College of Science, King Saudi University, \\ Riyadh 11451, Saudi Arabia; bparay@ksu.edu.sa \\ 3 Botany and Microbiology Department, College of Science, King Saudi University, \\ Riyadh 11451, Saudi Arabia; mnyemeni@ksu.edu.sa \\ 4 Department of Botany, S.P. College, Srinagar 190001, India \\ * Correspondence: parvaizbot@yahoo.com; Tel.: +98-58376669
}

Received: 25 November 2019; Accepted: 21 January 2020; Published: 29 January 2020

\begin{abstract}
In the current investigation, we studied role of Rhododendron leaf extract in Vigna radiata grown under chromium metal stress. We observed that seed treatment with Rhododendron leaf extract resulted in the recuperation of seedling growth under chromium toxicity. Seed treatment with Rhododendron leaf extract significantly improved the contents of anthocyanin and xanthophyll pigments under stress. The antioxidative defense system triggered after Rhododendron extract treatment, resulting in the increased actions of antioxidant enzymes. Oxidative stress induced by the assembly of reactive oxygen species was reduced after Rhododendron extract treatment under chromium toxicity as indicated by the enhanced contents of non-enzymatic antioxidants, namely ascorbic acid, tocopherol, and glutathione. Furthermore, Rhododendron leaf extract treatment under chromium metal stress also encouraged the biosynthesis of organic acids, polyphenols, as well as amino acids in Vigna radiata. Statistical analysis of the data with multiple linear regression also supported that Rhododendron leaf extract can effectively ease chromium metal-induced phytotoxicity in Vigna radiata.
\end{abstract}

Keywords: Rhododendron arboreum; Vigna radiata; enzymes activity; chromium (Cr); polyphenols

\section{Introduction}

Heavy metals, put forth by the modern urbanized and industrialized environment, are major chemical agents causing hindrances in normal growth, functioning, productivity, and survival of plants as well as animals [1]. In recent times, heavy metal toxicity in farming systems along with edible crops has become a major concernnot only from an environmental but also from a health point of view. Chromium $(\mathrm{Cr})$ is the prevalent element, whichexists in different oxidation states in nature, amongst which, the hexavalent chromium [Cr(VI)] is the most pernicious [2]. Volcanic dust and igneous rocks are the natural sources of chromium; however, agricultural land is severely contaminated with chromium metal by inappropriate waste dumping or seepage from tanneries and burning of coal or oil [3,4]. Usually, chromium is not persistent in the atmosphere as it is deftly deposited in soil or dissolved in water. Therefore, it is readily available to the roots of plants budding in the infected region. Even in low concentrations, $\mathrm{Cr}$ is reported to enhance the production of reactive oxygen species (ROS), including hydrogen peroxide $\left(\mathrm{H}_{2} \mathrm{O}_{2}\right)$ and superoxide anion, which lead to 
oxidative stress [5]. Oxidative stress hinders seed germination, growth, and metabolism in plants along with cell injury. Living organisms are equipped with an antioxidant defense system against ROS, which consists of enzymatic and non-enzymatic antioxidants [6]. Antioxidant enzymes include superoxide dismutase (SOD), catalase (CAT), ascorbate peroxidase (APOX), glutathione peroxidase (GPOX), guaiacol peroxidase (POD), polyphenol oxidase (PPO), dehydroascorbate reductase (DHAR), glutathione-S-transferase (GST), and glutathione reductase (GR) [7]. Non-enzymatic antioxidants comprise of ascorbic acid, tocopherol, glutathione (GSH), and polyphenols. Tocopherol repairs peroxyl radicals and terminates the chain of lipid peroxidation [8,9]. Thus, the antioxidative defense system helps to overcome oxidative stress. However, this system does not work efficiently when living organisms encounter severe metal stress, resulting in a need for external supplements to beat the oxidative stress.

A literature survey reveals the oxidative stress protective and plant growth regulatory effects of several plant extracts. For example, tea seed extract has been reported to regulate the growth of Brassica sp., Avena sativa, and Hordeum vulgare [10]. Rhododendron arboreum of the Ericaceae family is native to Bhutan, China, India, and Nepal. The trees grow in North and North-East India. The name 'rhododendron' is derived from the Greek word 'rhodo' meaning rose and 'dendron' meaning tree. Rhododendron is the national flower of Nepal and the state tree of Uttarakhand (India). This evergreen tree is important from an economical as well as a horticultural perspective. Also, it is widely used by the tribal people of North India for gastronomic as well as traditional restorative purposes. In our previous study [11], its antioxidant and antimutagenic properties were evaluated along with the active principals responsible for those activities. It has also been reported to be a resource of a number of phytoconstituents of therapeutic value by numerous authors [12-14]. So, keeping in view the eco-friendly and remunerative nature of plant extracts, the present study was designed to evaluate the $\mathrm{Cr}$ metal stress-ameliorating activity of Rhododendron arboreum leaves using Vigna radiata.

Due to its high protein content and low price, Vigna radiata has become the most widespread food item in every household all over the globe. In India, it is frequently used as food, especially for babies, old, and sick people, because of its easy digestibleness and great nutritional value. Its fiber is also an outstanding feed for farm animals. In addition, the capability of Vigna radiata to fix atmospheric nitrogen and add organic matter to the soil are major characteristics to maintain soil fertility. It has been previously reported that $\mathrm{Cr}$ exposure has harmful effects on the physiological and biochemical processes of Vigna radiata L [15]. Furthermore, metal stresses decrease the productivity of crops and go through the food chain, resulting in terrible health problems to the consumers, including human beings and other herbivores [16]. The Vigna radiata crop was selected for the present research since it fits well as a model because of its short life cycle and low maintenance nature.

The current analysis was carried out to investigate the effect of methanol extract of Rhododendron arboreum leaves (MEL) on Cr-treated Vigna radiata plants. The analyzed biochemical parameters included anthocyanin and xanthophyll pigment contents, antioxidant enzymes estimation, non-enzymatic antioxidants (ascorbic acid, tocopherol, and glutathione) analysis, and organic acids, polyphenols, and amino acids analysis.

\section{Materials and Methods}

The stress protective effect of methanol extract of Rhododendron arboreum leaves (MEL) on $\mathrm{Cr}(\mathrm{VI})$-treated Vigna radiata plants was observed by analyzing the pigment contents, protein content, enzymatic antioxidants, non-enzymatic antioxidants, polyphenols, amino acids, and organic acids.

\subsection{Raising of Plant Material}

The certified seeds of Vigna radiata var. SML-668 were procured from Punjab Agricultural University, Ludhiana (India). The healthy seeds of Vigna radiata were surface sterilized for one minute with $0.01 \%$ mercuric chloride $\left(\mathrm{HgCl}_{2}\right)$ and rinsed with distilled water several times. The seeds were given a pre-sowing treatment with different concentrations $(125,250$, and 500 ppm) of Rhododendron leaf extract 
for six hours. Petriplates lined with whatman filter paper 1 were supplemented with $250 \mu \mathrm{M}$ chromium (IV). These solutions were prepared in distilled water. The plants were grown in petriplates kept in a seed germinator for 7 days under controlled conditions of $25 \pm 0.5^{\circ} \mathrm{C}$ temperature, 16 -h photoperiod, 8-h dark period, $175 \mu \mathrm{mol} / \mathrm{m}^{2} / \mathrm{s}$ light intensity, and $60 \%$ relative humidity. After 7 days of growth, the plants were supplemented with half-strength Hoagland medium and the petriplates were monitored for 7 days, after which the plants were harvested and independent experiments were performed. Each petriplate contained 20 seeds and all the treatments were given in triplicates in order to ensure valid statistical analysis.

\subsection{Rhododendron arboreum Methanol Leaf Extract(MEL)}

The fresh leaves of Rhododendron arboreum leaves were washed with double-distilled water, dried in the shade, and ground to a fine powder in a mixergrinder. Them, $1 \mathrm{~kg}$ of powder was extracted with $80 \%$ methanol and dried in a vacuum rotary evaporator to get $68.38 \mathrm{~g}(6.83 \%)$ of methanol leaf extract. The nontoxic and maximum yield producing (in terms of the root length, shoot length, fresh weight, and dry weight) concentrations of the MEL (methanol extract of Rhododendron arboreum leaves) were identified by carrying out different test experiments on Vigna radiata seeds. Three concentrations, i.e., 125,250 , and 500 ppm, were selected for the present study. A 1000 ppm mother stock of MEL was prepared and working concentrations of 125,250 , and $500 \mathrm{ppm}$ were prepared from the mother stock by serial dilutions. The mother stock and working concentrations were stored in a refrigerator at $4{ }^{\circ} \mathrm{C}$.

\section{3. $\mathrm{Cr}(\mathrm{VI}) \mathrm{Metal}$}

Heavy metal $\mathrm{Cr}(\mathrm{VI})$ was given in the form of potassium chromate $\left(\mathrm{K}_{2} \mathrm{CrO}_{4}\right)$ (Qualigens Fine Chemicals Pvt. Ltd., Mumbai, India). The $\mathrm{IC}_{50}$ value $(250 \mu \mathrm{M})$ of the metal was determined and used for the treatments. The working $250 \mu \mathrm{M}$ concentration of $\mathrm{Cr}(\mathrm{VI})$ was prepared from $10 \mathrm{mM}$ mother stock.

\subsection{Treatments}

All the treatments given in the present study are shown in Table 1.

Table 1. Different treatments given to Vigna radiata in the present investigation.

\begin{tabular}{cccc}
\hline Sr. No. & Name of the Treatment & MEL $(\mathbf{p p m})$ & $\mathbf{C r}(\mathrm{VI})(\boldsymbol{\mu M})$ \\
\hline 1. & Control & 0 & 0 \\
2. & MEL-1 & 125 & 0 \\
3. & MEL-2 & 250 & 0 \\
4. & MEL-3 & 500 & 0 \\
5. & Cr(VI) & 0 & 250 \\
6. & Cr(VI) + MEL-1 & 125 & 250 \\
7. & Cr(VI) + MEL-2 & 250 & 250 \\
8. & Cr(VI) + MEL-3 & 500 & 250 \\
\hline
\end{tabular}

\subsection{Phenolic Pigments:}

\subsubsection{Xanthophyll Content}

The plant tissue was tested for xanthophyll content using the method of Lawrence [17]. Hexane, acetone, absolute alcohol, and toluene were mixed in the ratio of 10:7:6:7 to prepare the extractant. Then, $50 \mathrm{mg}$ of dried plant sample was converted into a fine powder using a pestle and mortar. The powdered plant sample was mixed with $30 \mathrm{~mL}$ of extractant solution in a volumetric flask and shaken for 10-15 min. The hot saponification process was started by adding $2 \mathrm{~mL}$ of methanolic $\mathrm{KOH}(40 \%)$. The contents were shaken for 1-2 min, then the flask was kept at $56^{\circ} \mathrm{C}$ in a water bath followed by incubation for one hour in cool dark conditions. Then, $30 \mathrm{~mL}$ of hexane was added to the reaction mixture with continued vigorous shaking and the final volume of $100 \mathrm{~mL}$ was made with the addition 
of $10 \% \mathrm{Na}_{2} \mathrm{SO}_{3}$. The flask was again incubated for one hour in dark conditions. The absorbance (A) of the upper phase was noted at $474 \mathrm{~nm}$.

\subsubsection{Anthocyanin Content}

The anthocyanin content of the fresh plant sample was estimated by the method given by Mancinelli [18]. Under chilled conditions, $1 \mathrm{~g}$ of fresh plant sample was crushed using a pestle and mortar, in an extraction mixture, which consisted of methanol, distilled water, and hydrochloric acid in a ratio of 79:20:1. The crushed tissue was centrifuged for $20 \mathrm{~min}$ at $13,000 \mathrm{rpm}$ and $4{ }^{\circ} \mathrm{C}$. The A of the supernatant was recorded at 530 and $657 \mathrm{~nm}$.

\subsection{Protein Content}

The protein content of the samples was determined by following the method given by Lowry et al. [19]. Onegram of fresh plant samples was weighed and crushed in $3 \mathrm{~mL}$ of $50 \mathrm{mM}$ potassium phosphate buffer with $\mathrm{pH} 7.0$ using a pestle and mortar under ice cold conditions. The homogenates were centrifuged for $20 \mathrm{~min}$ at $13,000 \mathrm{rpm}$ and $4{ }^{\circ} \mathrm{C}$. In total, $100 \mu \mathrm{L}$ of supernatant was mixed with $900 \mu \mathrm{L}$ of distilled water followed by the addition of $5 \mathrm{~mL}$ of reagent $\mathrm{C}$. The test tube with $1 \mathrm{~mL}$ of distilled water served as a blank. This mixture was mixed well and allowed to stand for $10 \mathrm{~min}$ followed by the addition of $500 \mu \mathrm{L}$ of Folin-Ciocalteau reagent. The reaction mixture was mixed thoroughly and incubated at room temperature for $30 \mathrm{~min}$ in dark conditions. The optical density of the blue color was measured at $660 \mathrm{~nm}$. A standard curve of the protein solution representing concentration vs. absorbance was plotted and a linear regression equation was obtained, which was used to calculate the protein content of the samples, which was expressed as $\mathrm{mg} \mathrm{g}^{-1}$ fresh weight.

\subsection{Enzymatic Antioxidants}

\subsubsection{Preparation of Plant Extracts}

Onegram of fresh plant sample was weighed and crushed in $3 \mathrm{~mL}$ of extractant buffer using a pestle and mortar under ice cold conditions. The homogenates were centrifuged for $20 \mathrm{~min}$ at $13,000 \mathrm{rpm}$ and $4^{\circ} \mathrm{C}$. The supernatant was collected for analysis of the biochemical parameters. The extractant buffer for the estimation of the activities of (POD, CAT, GR, APOX, DHAR, and GPOX) enzymes was $50 \mathrm{mM}$ potassium phosphate buffer with $\mathrm{pH}$ 7.0. For estimation of the SOD activity, samples were homogenized in $50 \mathrm{mM}$ sodium carbonate buffer at $\mathrm{pH}$ 10.2. The homogenates for GST were prepared in $0.2 \mathrm{M}$ potassium phosphate buffer with $\mathrm{pH} 7.4$ whereas for PPO, $0.1 \mathrm{M}$ potassium phosphate buffer at $\mathrm{pH} 7.0$ was used.

\subsubsection{Guaiacol Peroxidase (POD, EC. 1.11.1.7)}

The guaiacol peroxidase activity was estimated by method given by Pütter [20]. To prepare $3 \mathrm{~mL}$ of the reaction mixture $50 \mathrm{mM}$ phospahte buffer, $20.1 \mathrm{mM}$ of guaiacol solution, $12.3 \mathrm{mM}$ of $\mathrm{H}_{2} \mathrm{O}_{2}$, and $60 \mu \mathrm{L}$ of enzyme extract were added to a cuvette. The rate of the oxidation of guaiacol and formation of guaiacol dehydrogenation product (GDHP) was recorded at $436 \mathrm{~nm}$ for $1 \mathrm{~min}$ at 3-s intervals at $25^{\circ} \mathrm{C}$. One unit of enzyme activity is defined as the amount of enzyme necessary to catalyze the oxidation of guaiacol and the development of $1 \mu \mathrm{M}$ of GDHP $\min ^{-1} \mathrm{~g}^{-1}$ fresh weight. The enzyme activity was expressed as UA $\mathrm{mg} \mathrm{g}^{-1}$ protein.

\subsubsection{Catalase (CAT, EC 1.11.1.6)}

The estimation of the catalase activity was performed according to the method of Aebi [21]. First, $3 \mathrm{~mL}$ of the reaction mixture consisted of $50 \mathrm{mM}$ phosphate buffer, $15 \mathrm{mM} \mathrm{H}_{2} \mathrm{O}_{2}$, and $60 \mu \mathrm{L}$ of enzyme extract. The breakdown of hydrogen peroxide caused a decline in the optical density, which was recorded for one minute at $240 \mathrm{~nm}$ and $25^{\circ} \mathrm{C}$. The quantity of enzyme necessary to release 
half peroxide oxygen from hydrogen peroxide is referred to as one unit of the enzyme activity and was expressed as UA $\mathrm{mg} \mathrm{g}^{-1}$ protein

\subsubsection{Superoxide Dismutase (SOD, EC 1.15.1.1)}

The superoxide dismutase activity of the fresh plant samples was estimated by the method proposed by Kono [22]. To estimate the SOD activity, a reaction mixture containing $50 \mathrm{mM}$ sodium carbonate buffer, $24 \mu \mathrm{M}$ Nitro Blue Tetrazolium (NBT), $0.1 \mathrm{mM}$ ethylenediaminetetraacetic acid (EDTA), and $0.03 \%$ Triton X-100 was put in a cuvette and the reaction was started by the addition of $1 \mathrm{mM}$ hydroxylamine hydrochloride. Then, $70 \mu \mathrm{L}$ of enzyme extract were added to the reaction mixture and the increase in the absorbance was observed at $560 \mathrm{~nm}$ for 2 min at 6-s intervals at $25{ }^{\circ} \mathrm{C}$. The amount of enzyme required to inhibit NBT reduction up to $50 \%$ is defined as one unit of enzyme and was expressed as UA $\mathrm{mg} \mathrm{g}^{-1}$ protein.

\subsubsection{Ascorbate Peroxidase (APOX, EC. 1.11.1.11)}

The APOX activity of plant samples was estimated by following the method given by Nakano and Asada [23]. First, $50 \mathrm{mM}$ phosphate buffer, $0.5 \mathrm{mM}$ ascorbate, $1 \mathrm{mM} \mathrm{H}_{2} \mathrm{O}_{2}$, and $70 \mu$ Lof enzyme extract comprised the $3 \mathrm{~mL}$ reaction mixture. The decrease in absorbance was recorded at 290 $\mathrm{nm}$. One unit of ascorbate peroxidase was estimated by measuring the amount of enzyme required to oxidize $1 \mu \mathrm{M}$ of ascorbate $\mathrm{min}^{-1} \mathrm{~g}^{-1}$ fresh weight. The APOX activity was expressed as UA mg $\mathrm{g}^{-1}$ protein

\subsubsection{Glutathione Reductase (GR, EC 1.6.4.2)}

The glutathione reductase activity of fresh plant samples was assayed by using the method proposed by Carlberg and Mannervik [24]. The 3-mL reaction mixture in the cuvette consisted of $50 \mathrm{mM}$ phosphate buffer, $1 \mathrm{mM}$ EDTA, $0.1 \mathrm{mM}$ reduced nicotinamide adenine dinucleotide phosphate (NADPH), $1 \mathrm{mM}$ glutathione disulphide, and $75 \mu \mathrm{L}$ of enzyme extract. The decrease in absorbance per minute was observed at $340 \mathrm{~nm}$ at intervals of $3 \mathrm{~s}$ at $25^{\circ} \mathrm{C}$. One unit of enzyme activity is defined as the amount of enzyme required to oxidize $1.0 \mu \mathrm{M}$ of NADPH min ${ }^{-1} \mathrm{~g}^{-1}$ fresh weight. The activity was expressed as UA $\mathrm{mg} \mathrm{g}^{-1}$ protein.

\subsubsection{Dehydroascorbate Reductase (DHAR, EC. 1.8.5.1)}

The dehydroascorbate reductase activity of plant samples was estimated using the method given by Dalton et al. [25]. The 3-mL reaction mixture contained $50 \mathrm{mM}$ phosphate buffer, $0.1 \mathrm{mM}$ EDTA, $1.5 \mathrm{mM}$ reduced glutathione and $0.2 \mathrm{mM}$ dehydroascorbate, and $75 \mu \mathrm{L}$ of enzyme extract. An increase in the absorbance per minute was noted at $265 \mathrm{~nm}$ at 3-s intervals and $25{ }^{\circ} \mathrm{C}$. One unit of dehydroascorbate reductase is defined as the quantity of enzyme needed to catalyze the development of $1 \mu \mathrm{M}$ of ascorbate $\mathrm{min}^{-1} \mathrm{~g}^{-1}$ fresh weight of plant tissue. The DHAR activity was indicated by UA $\mathrm{mg} \mathrm{g}^{-1}$ protein.

\subsubsection{Polyphenol Oxidase (PPO, EC 1.10.3.1)}

The polyphenol oxidase activity was estimated according to the method proposed by Kumar and Khan [26]. For the estimation of the enzyme, $1 \mathrm{~mL}$ of phosphate buffer, $0.5 \mathrm{~mL}$ of catechol, and $0.25 \mathrm{~mL}$ of enzyme extract were added to the cuvette and it was incubated for $2 \mathrm{~min}$. The reaction was initiated by the addition of $0.5 \mathrm{~mL}$ of $\mathrm{H}_{2} \mathrm{SO}_{4}$ and any change in absorbance was noted at $495 \mathrm{~nm}$ for $1 \mathrm{~min}$. One unit of enzyme activity is defined as the quantity of enzyme necessary to oxidize $1 \mu \mathrm{M}$ of catechol. The activities of the enzyme were expressed as UA $\mathrm{mg} \mathrm{g}^{-1}$ protein. 


\subsubsection{Glutathione-S-Transferase (GST, EC 2.5.1.13)}

The glutathione-S-transferase enzyme activity was estimated according to the method given by Habig and Jakoby [27]. The 3-mL reaction mixture in the cuvette contained $0.2 \mathrm{M}$ phosphate buffer, $1 \mathrm{mM}$ each of GSH and 1-Chloro-2,4-dinitrobenzene (CDNB), and the reaction was set off by adding $70 \mu \mathrm{L}$ of enzyme extract. The increase in absorbance at $340 \mathrm{~nm}$ was recorded for $1 \mathrm{~min}$ at 3 -s intervals. One unit of enzyme activity is defined as the quantity of enzyme catalyzing the development of $1 \mu \mathrm{M}$ of conjugated GSH-CDNB $\min ^{-1} \mathrm{~g}^{-1}$ plant tissue at $25^{\circ} \mathrm{C}$. The activity was revealed as UA $\mathrm{mg} \mathrm{g}^{-1}$ protein.

\subsubsection{Glutathione Peroxidase (GPOX, EC 1.11.1.7)}

The glutathione peroxidase activity of fresh plant samples was analyzed according to the method given by Flohé and Günzler [28]. The composition of the 3-mL reaction mixture in the cuvette consisted of $50 \mathrm{mM}$ phosphate buffer, $0.5 \mathrm{mM}$ EDTA, $1 \mathrm{mM}$ of GSH, $1 \mathrm{mM}$ of sodium azide, $0.15 \mathrm{mM}$ $\mathrm{NADPH}$ and $0.15 \mathrm{mM} \mathrm{H}_{2} \mathrm{O}_{2}$, and $75 \mu \mathrm{L}$ of enzyme extract. A decrease in the absorbance due to oxidation of NADPH was measured for $1 \mathrm{~min}$ at $340 \mathrm{~nm}$ at 3-s intervals. One unit of enzyme activity is defined as the amount of enzyme required to oxidize $1.0 \mu \mathrm{M}$ of NADPH $\min ^{-1} \mathrm{~g}^{-1}$ fresh tissue at $37^{\circ} \mathrm{C}$ and the activities were revealed as UA $\mathrm{mg} \mathrm{g}^{-1}$ protein.

\subsection{Non-Enzymatic Antioxidants}

\subsubsection{Ascorbic Acid Content}

The ascorbic acid content was estimated by the method of Roe and Kuether [29]. First, $1 \mathrm{~g}$ of fresh plant sample was crushed in $3 \mathrm{~mL}$ of $50 \mathrm{mM}$ Tris buffer $(\mathrm{pH} 10)$ using a pestle and mortar under chilled conditions. The homogenate was centrifuged at $13,000 \mathrm{rpm}$ and $4{ }^{\circ} \mathrm{C}$ for $20 \mathrm{~min}$. Then, $500 \mu \mathrm{L}$ of supernatant were mixed with 4 mLof distilled water, $0.5 \mathrm{~mL} 50 \%$ TCA, and $100 \mathrm{mg}$ of activated charcoal in test tubes. The mixture was thoroughly mixed and filtered through Whatman filter paper No. 1 . To the filtrate, $0.4 \mathrm{~mL}$ of 2,4-Dinitrophenylhydrazine (DNPH) reagent was added and incubation was given at $37^{\circ} \mathrm{C}$ for $3 \mathrm{~h}$. Cooling was done using an ice bath followed by the addition of $1.6 \mathrm{~mL}$ of cold $\mathrm{H}_{2} \mathrm{SO}_{4}(65 \%)$. Again, incubation was given for $30 \mathrm{~min}$ at room temperature and the absorbance was taken at $520 \mathrm{~nm}$. Ascorbic acid in the concentration of $1 \mathrm{mg} / 100 \mathrm{~mL}$ was used as a standard and its content in the sample was expressed as $\mathrm{mg}$ ascorbic acid $\mathrm{g}^{-1}$ fresh weight.

\subsubsection{Tocopherol Content}

Tocopherol (vitamin E) was estimated by the method given by Martinek [30]. First, $1 \mathrm{~g}$ of fresh plant sample was crushed in $3 \mathrm{~mL}$ of $50 \mathrm{mM}$ Tris buffer ( $\mathrm{pH}$ 10) using a pestle and mortar under chilled conditions. The homogenate was centrifuged at $13,000 \mathrm{rpm}$ and $4{ }^{\circ} \mathrm{C}$ for $20 \mathrm{~min}$. Then, $500 \mu \mathrm{L}$ of supernatant were mixed with $500 \mu \mathrm{L}$ distilled water and $500 \mu \mathrm{L} \mathrm{FeCl}_{3}(0.12 \%$ in absolute ethanol) in test tubes followed by vigorous shaking until precipitates formed. The reaction mixture was mixed with $500 \mu \mathrm{L}$ xylene and vortexed for $30 \mathrm{~s}$. The solution was centrifuged for $10 \mathrm{~min}$ at $3000 \mathrm{rpm}$. The upper xylene layer was mixed with an equal volume of 2,4,6-Tripyridyl-S-triazine (TPTZ) $(12 \%$ in

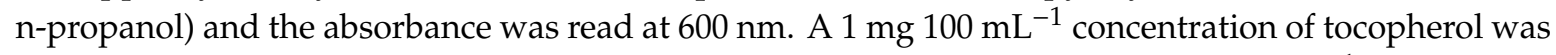
used as the standard tocopherol content in sample and was expressed as $\mathrm{mg}$ tocopherol $\mathrm{g}^{-1}$ fresh weight.

\subsubsection{Glutathione Content}

The GSH content was estimated by the method given by Sedlak and Lindsay [31]. First, $1 \mathrm{~g}$ of fresh plant sample was crushed in $3 \mathrm{~mL}$ of $0.2 \mathrm{M}$ Tris buffer ( $\mathrm{pH}$ 8.2) using a pestle and mortar under chilled conditions. The homogenate was centrifuged at $13,000 \mathrm{rpm}$ and $4{ }^{\circ} \mathrm{C}$ for $20 \mathrm{~min}$. Then, $100 \mu \mathrm{L}$ of supernatant was mixed with $1 \mathrm{~mL}$ of $0.2 \mathrm{M}$ Tris buffer (pH 8.2), $50 \mu \mathrm{L}$ DTNB (5,5'-dithiobis2-nitrobenzoic acid), and $4 \mathrm{~mL}$ of absolute methanol in test tubes followed by an incubation of $15 \mathrm{~min}$ at room temperature. The reaction mixture was centrifuged for $15 \mathrm{~min}$ at $3000 \mathrm{rpm}$ and the absorbance of 
the supernatant was noted at $412 \mathrm{~nm}$. GSH at a concentration of $1 \mathrm{mg} 100^{-1} \mathrm{~mL}$ was used as a standard for determining the GSH content in the sample. The value was expressed as $\mathrm{mg} \mathrm{GSH} \mathrm{g}^{-1}$ fresh weight.

\subsubsection{Glutathione Imaging}

Tagging of glutathione in the roots of Vigna radiata was done with MCB (monochlorobimane) dye according to the method of Hartmann et al. [32]. MCB produces a fluorescent adduct with GSH. In the meanwhile, sodium azide depletes adenosine triphosphate (ATP) from the cells in order to avoid vacuolar seizure of the MCB-GSH adduct caused by ATP. The root samples were dipped in the $25 \mu \mathrm{M}$ MCB dye containing $5 \mathrm{mM}$ sodium azide for about 15 to $20 \mathrm{~min}$. Samples were then mounted in distilled water on a glass slide and covered with a cover slip. The slides were then observed under a confocal microscope at an excitation wavelength of 351-364 nm and emission wavelength of $477 \mathrm{~nm}$. The intensity of the blue color indicates the measure of glutathione in the roots.

\subsection{Polyphenol Estimation}

Qualitative as well as quantitative analysis of the plant samples for polyphenolic compounds was carried out using ultra-high-performance liquid chromatography (UHPLC). First, $500 \mathrm{mg}$ of fresh plant material were crushed in $2 \mathrm{~mL}$ of high-performance liquid chromatography (HPLC)-grade methanol using a pestle and mortar. The solution was centrifuged at 13,000 rpm for $20 \mathrm{~min}$ and filtered using 0.2-micron filter paper. The portrayal of phenolic compounds was executed using a $130 \mathrm{MPa}$ Shimadzu UHPLC (Nexera) system, equipped with a DGU-20As prominence degasser, LC-30AD liquid chromatograph, SIL-30AC autosampler, CTO-10AS VP column oven, CBM-20A communications bus module, and SPD-M20A photodiode array detector (PDA). The chromatography was carried out at room temperature with a flow rate of $1 \mathrm{~mL} / \mathrm{min}$ at $\lambda 280 \mathrm{~nm}$. A $150 \times 4.6 \mathrm{~mm} \mathrm{C}-18$ column with a pore size of $5 \mu \mathrm{m}$ was used. The injection volume was $5 \mu \mathrm{L}$. The solvent system comprised of solvent A (0.01\% acetic acid in water) and solvent B (methanol). The gradient runs were $70 \% \mathrm{~A}$ and $30 \% \mathrm{~B}$, reaching $45 \% \mathrm{~B}$ at $12 \mathrm{~min}, 75 \% \mathrm{~B}$ at $13.5 \mathrm{~min}, 75 \% \mathrm{~B}$ at $15 \mathrm{~min}, 50 \% \mathrm{~B}$ at $16.6 \mathrm{~min}, 25 \% \mathrm{~B}$ at $18 \mathrm{~min}$, $25 \% \mathrm{~B}$ at $20 \mathrm{~min}, 30 \% \mathrm{~B}$ at $21 \mathrm{~min}$, and stopped at $22 \mathrm{~min}$, with an elution of $4 \mathrm{~min}$. The mixture of 11 polyphenolic standards, namely gallic acid $\left(\mathrm{C}_{7} \mathrm{H}_{6} \mathrm{O}_{5}\right)$, catechin $\left(\mathrm{C}_{15} \mathrm{H}_{14} \mathrm{O}_{6}\right)$, chlorogenic acid $\left(\mathrm{C}_{16} \mathrm{H}_{18} \mathrm{O}_{9}\right)$, epicatechin $\left(\mathrm{C}_{15} \mathrm{H}_{14} \mathrm{O}_{6}\right)$, caffeic acid $\left(\mathrm{C}_{9} \mathrm{H}_{8} \mathrm{O}_{4}\right)$, umbelliferone $\left(\mathrm{C}_{9} \mathrm{H}_{6} \mathrm{O}_{3}\right)$, coumaric acid $\left(\mathrm{C}_{9} \mathrm{H}_{8} \mathrm{O}_{3}\right)$, rutin $\left(\mathrm{C}_{27} \mathrm{H}_{30} \mathrm{O}_{16}\right)$, ellagic acid $\left(\mathrm{C}_{14} \mathrm{H}_{6} \mathrm{O}_{8}\right)$, quercetin $\left(\mathrm{C}_{15} \mathrm{H}_{10} \mathrm{O}_{7}\right)$, and kaempferol $\left(\mathrm{C}_{15} \mathrm{H}_{10} \mathrm{O}_{6}\right)$, was diluted with methanol at different concentrations by serial dilution for quantitative analysis. The calibration curves were generated by plotting the concentrations versus peak areas. The detection of every compound was based on a combination of the retention time and spectral similarity. The detection and quantification limit for all the detected compounds were calculated on the basis of signal-to-noise ratio $(\mathrm{S} / \mathrm{N})$ of 3 and 10 with the corresponding standard solution, respectively.

\subsection{Amino Acid Profiling}

The amino acid analysis was done using an amino acid analyzer by making slight modifications to the method given by Iriti et al. [33]. First, $0.25 \mathrm{mg}$ of fresh plant sample were crushed in $1.25 \mathrm{~mL}$ of $80 \%$ methanol using a pestle and mortar in chilled conditions. The homogenized sample was centrifuged for $20 \mathrm{~min}$ at $13,000 \mathrm{rpm}$. The supernatant was mixed with $6 \%$ sulfosalicylic acid in a ratio of 1:1 and the solution was further diluted with $0.1 \mathrm{~N} \mathrm{HCl}$ in a ratio of 1:4. The solution was filtered using 0.2-micron filter paper. Using an auto sampler, $1 \mu \mathrm{L}$ of sample was injected into the C-18 silica-bonded, 150-mm-long amino acid column with a pore size of $120 \AA$ and particle size of $5 \mu \mathrm{m}$. The amino acid analysis was carried out using a Shimadzu, Nexera $X_{2}$ amino acid analyzer. A 150-mm-long C-18 silica-bonded column with a $120 \AA$ A pore size and 5 micrometer particle size was used for the analysis of amino acids. The injection volume was $1 \mu \mathrm{L}$, run time was $32 \mathrm{~min}$, oven temperature was $40^{\circ} \mathrm{C}$, and pump flow rate was $1 \mathrm{~mL} \mathrm{~min}^{-1}$. Mobile phase " $\mathrm{A}$ " consisted of $5.6 \mathrm{pH}$ phosphate buffer; mobile phase " $\mathrm{B}$ " comprised of ultra-pure water, methanol, and acetonitrile in the ratio of 15:40:45. The detection of every amino acid was based on a combination of the retention 
time and spectral similarity. The detection and quantification limits for all the detected amino acids were calculated on the basis of the signal-to-noise ratio $(\mathrm{S} / \mathrm{N})$ of 3 and 10 with the corresponding standard solution, respectively.

\subsection{Organic Acid Profiling}

Organic acids in the test samples of 7-day-old Vigna radiata plants were estimated using GC-MS according to the method given by Chen et al. [34]. The 7-day-old Vigna radiata plants were washed with distilled water, dried at room temperature, and crushed to make powder with the help of a pestle and mortar. Then, $50 \mathrm{mg}$ of powder of the dried plant sample was mixed with $500 \mu \mathrm{L}$ of $0.5 \mathrm{~N} \mathrm{HCl}$ and $500 \mu \mathrm{L}$ of methanol. The mixture was shaken for $3 \mathrm{~h}$ followed by centrifugation for $10 \mathrm{~min}$ at $10,000 \times \mathrm{g}$. To the supernatant, $300 \mu \mathrm{L}$ of methanol and $100 \mu \mathrm{L}$ of $50 \% \mathrm{H}_{2} \mathrm{SO}_{4}$ were added and overnight incubation was given at $60^{\circ} \mathrm{C}$ using a water bath. The solution was cooled to $25^{\circ} \mathrm{C}$ followed by the addition of $800 \mu \mathrm{L}$ of chloroform and $400 \mu \mathrm{L}$ of distilled water. The solution was subjected to vortexing for one minute and the lower chloroform layer was used for the assessment of organic acids. To estimate the content of organic acids, $2 \mu \mathrm{L}$ of the chloroform layer were injected into the GC-MS system (Shimadzu GC-MS-QP2010 Plus) in split mode. A DB-5 ms analytical column was used and the initial column temperature for one minute was $50{ }^{\circ} \mathrm{C}$, which was raised to $125^{\circ} \mathrm{C}$ at a rate of $25^{\circ} \mathrm{C} \mathrm{min}-1$ followed by a further increase to $300{ }^{\circ} \mathrm{C}$ at a rate of $10^{\circ} \mathrm{C} / \mathrm{min}$ and held for $15 \mathrm{~min}$. The injection temperature was $250^{\circ} \mathrm{C}$, the carrier gas used was helium, and the gas flow in the column was $1.7 \mathrm{~mL} \mathrm{~min}^{-1}$. The ion source temperature and interface temperature was set at $200{ }^{\circ} \mathrm{C}$ and $280{ }^{\circ} \mathrm{C}$, respectively. The quantification of organic acids was done using a standard curve.

\subsection{Statistical Analysis}

All experimental measurements were carried out in triplicate. The mean values and standard error were calculated. The data were analyzed statistically by two-way analysis of variance (ANOVA), as described by Bailey [35]. Tukey's multiple comparison test was used to compare the difference among means by using the honest significant difference HSD values. Comparisons with $P$-values $\leq 0.05$ were considered as significantly different. Multiple regression analysis with interaction (MLR) was carried out to identify the nature of the effect brought about by independent variables $\mathrm{Cr}$, MEL, and their interaction $(\mathrm{Cr}(\mathrm{VI}) \times \mathrm{MEL}) . \beta$-regression values provided the relative effects of the independent variables:

$$
\mathrm{X}_{1}=\mathrm{Cr}(\mathrm{VI}), \mathrm{X}_{2}=\mathrm{MEL} \text { and } \mathrm{X}_{1} \mathrm{X}_{2}=\mathrm{Cr}(\mathrm{VI}) \times \mathrm{MEL} .
$$

\section{Results}

\subsection{Phenolic Pigments}

The data obtained on alterations in the contents of anthocyanin and xanthophylls pigments due to the effect of different treatments of $\mathrm{Cr}(\mathrm{VI}), \mathrm{MEL}$, and their interaction in Vigna radiata plants are presented in Table 2. It was noted that in relation to $1.2 \mu \mathrm{g}$ anthocyanin $\mathrm{g}^{-1} \mathrm{FW}$ in control plants, the anthocyanin content in 7-day-old plants of Vigna radiata increased to $13.75 \mu \mathrm{g} \mathrm{g}^{-1} \mathrm{FW}$ with the $\mathrm{Cr}(\mathrm{VI})$ metal treatment. MEL application to $\mathrm{Cr}(\mathrm{VI})$-treated plants further enhanced the content and the plants grown in combination with $\mathrm{Cr}(\mathrm{VI})$ and $500 \mathrm{ppm}$ MEL showed a maximum increase of $36.61 \mu \mathrm{g} \mathrm{g}^{-1}$ FW in the anthocyanin content. Various treatments had a significant role in modulating the increase of the xanthophylls pigment. The xanthophyll content in 7-day-old $\mathrm{Cr}(\mathrm{VI})$ metal-stressed plants was elevated to $28.81 \mathrm{\mu g} \mathrm{g}^{-1} \mathrm{FW}$ in contrast to $16.1 \mu \mathrm{g} \mathrm{g}^{-1} \mathrm{FW}$ in control plants. The exogenous supplementation of MEL at the 125, 250, and $500 \mathrm{ppm}$ concentrations to $\mathrm{Cr}(\mathrm{VI})$-stressed plants further enhanced the xanthophyll content to $34.95,42.37$, and $48.94 \mu \mathrm{g} \mathrm{g}^{-1} \mathrm{FW}$, respectively. Anthocyanin (HSD 5.92) and xanthophylls (HSD 5.67) showed a statistically significant difference in the two-way ANOVA analysis. Positive $\beta$ values in the MLR analysis indicated the positive effect of $\mathrm{Cr}(\mathrm{VI})$, and the interaction of $\mathrm{Cr}(\mathrm{VI}) \times$ MEL on the anthocyanin and xanthophyll contents. 
Table 2. Effect of $\mathrm{Cr}(\mathrm{VI})$, different concentrations of methanol extract of Rhododendron arboreum leaves (MEL), and their combinations on anthocyanin and xanthophyll content in 7-day-old Vigna radiata seedlings. The values are the means of three replicates \pm S.D. (standard deviation). Tukeys test performed and significance checked at ${ }^{*} p \leq 0.05$. the $\mathrm{F}$ ratio is the term in which ANOVA is represented; $\mathrm{Cr}(\mathrm{VI})=$ Dose, MEL treatments $=$ Treatment and combination of $\mathrm{Cr}(\mathrm{VI})$ and MEL $=$ Dose $\times$ treatment.

\begin{tabular}{|c|c|c|c|c|c|}
\hline \multicolumn{2}{|r|}{ Concentrations } & \multirow{2}{*}{\multicolumn{2}{|c|}{ Anthocyanin $\left(\mu \mathrm{g} \mathrm{g}^{-1} \mathrm{FW}\right)$}} & \multirow{2}{*}{\multicolumn{2}{|c|}{ Xanthophyll ( $\left.\mu \mathrm{g} \mathrm{g}^{-1} \mathrm{FW}\right)$}} \\
\hline $\operatorname{Cr}(\mathrm{VI})(\mu \mathrm{M})$ & MEL (ppm) & & & & \\
\hline 0 & 0 & \multicolumn{2}{|c|}{$1.20 \pm 0.58$} & \multicolumn{2}{|c|}{$16.10 \pm 0.97$} \\
\hline 0 & 125 & \multicolumn{2}{|c|}{$2.78 \pm 1.11$} & \multicolumn{2}{|c|}{$18.85 \pm 1.32$} \\
\hline 0 & 250 & \multicolumn{2}{|c|}{$5.39 \pm 1.12$} & \multicolumn{2}{|c|}{$22.24 \pm 0.63$} \\
\hline 0 & 500 & \multicolumn{2}{|c|}{$11.89 \pm 1.37$} & \multicolumn{2}{|c|}{$25.21 \pm 1.94$} \\
\hline 250 & 0 & \multicolumn{2}{|c|}{$13.75 \pm 0.42$} & \multicolumn{2}{|c|}{$28.81 \pm 0.97$} \\
\hline 250 & 125 & \multicolumn{2}{|c|}{$17.47 \pm 3.23$} & \multicolumn{2}{|c|}{$34.95 \pm 2.54$} \\
\hline 250 & 250 & \multicolumn{2}{|c|}{$24.34 \pm 3.20$} & \multicolumn{2}{|c|}{$42.37 \pm 3.19$} \\
\hline 250 & 500 & \multicolumn{2}{|c|}{$36.61 \pm 3.07$} & \multicolumn{2}{|c|}{$48.94 \pm 2.77$} \\
\hline \multicolumn{2}{|c|}{ F-ratio Treatment $(1,16)$} & \multicolumn{2}{|c|}{$429.96^{*}$} & \multicolumn{2}{|c|}{$492.25^{*}$} \\
\hline \multicolumn{2}{|c|}{ F-ratio Dose $(3,16)$} & \multicolumn{2}{|c|}{$74.46^{*}$} & \multicolumn{2}{|c|}{$60.38^{*}$} \\
\hline F-rat & Treatment $\times$ Dose $_{(3,16)}$ & \multicolumn{2}{|c|}{$9.86^{*}$} & \multicolumn{2}{|c|}{$8.55^{*}$} \\
\hline \multicolumn{2}{|r|}{ HSD } & \multicolumn{2}{|c|}{5.92} & \multicolumn{2}{|c|}{5.67} \\
\hline \multirow{2}{*}{ Parameter } & \multirow{2}{*}{ MLR Equation } & \multicolumn{3}{|c|}{$\beta$-Regression Coefficient } & \multirow{2}{*}{$\begin{array}{l}\text { Multiple } \\
\text { Correlation }\end{array}$} \\
\hline & & $\mathrm{Cr}(\mathrm{VI})$ & (MEL) & $(\mathrm{Cr}(\mathrm{VI}) \times \mathrm{MEL})$ & \\
\hline Anthocyanin & $\begin{array}{c}\mathrm{Y}=0.53+0.04 \mathrm{Cr}(\mathrm{VI})+0.02 \\
(\mathrm{MEL})+0.0001(\mathrm{Cr}(\mathrm{VI}) \times \mathrm{MEL})\end{array}$ & 0.54 & 0.36 & 0.38 & $0.99^{*}$ \\
\hline Xanthophyll & $\begin{array}{c}\mathrm{Y}=16.61+0.05 \mathrm{Cr}(\mathrm{VI})+0.01 \\
\left.(\mathrm{MEL})+9 \times 10^{-5} \mathrm{Cr}(\mathrm{VI}) \times \mathrm{MEL}\right)\end{array}$ & 0.61 & 0.31 & 0.34 & $0.99^{*}$ \\
\hline
\end{tabular}

\subsection{Protein Content}

Table 3 represents the variations in the protein content of 7-day-old Vigna radiata plants due to $\mathrm{Cr}(\mathrm{VI})$ treatment and MEL supplementation. The protein content in untreated plants was observed to be $18.70 \mathrm{mg} \mathrm{g}^{-1} \mathrm{FW}$, which lowered to $9.60 \mathrm{mg} \mathrm{g}^{-1} \mathrm{FW}$ in the $\mathrm{Cr}(\mathrm{VI})$-treated plants. The supplementation of 125,250 , and 500 ppm MEL concentrations to the $\mathrm{Cr}(\mathrm{VI})$-treated plants resulted in the elevation of the protein content to $12.60,15.73$, and $16.83 \mathrm{mg} \mathrm{g}^{-1} \mathrm{FW}$, respectively. The ANOVA analysis depicted a statistically significant difference in the protein content, with an HSD value of 1.57 (Table 4). The MLR analysis revealed the negative impact of $\mathrm{Cr}(\mathrm{VI})$ treatment (negative $\beta$ value) and positive impact of the $\mathrm{Cr}(\mathrm{VI}) \times$ MEL application (positive $\beta$ value) on the protein content.

Table 3. Effect of $\mathrm{Cr}(\mathrm{VI})$, different concentrations of methanol extract of Rhododendron arboreum leaves (MEL), and their combinations on the protein content and activities of superoxide dismutase (SOD) and guaiacol peroxidase (POD) enzymes in 7-day-old Vigna radiata seedlings. The values are the means of three replicates \pm S.D. (standard deviation). Tukeys test performed and significance checked at ${ }^{*} p \leq 0.05$. The $\mathrm{F}$ ratio is the term in which ANOVA is represented; $\mathrm{Cr}(\mathrm{VI})=$ Dose, MEL treatments $=$ Treatment and combination of $\mathrm{Cr}(\mathrm{VI})$ and MEL $=$ Dose $\times$ treatment.

\begin{tabular}{|c|c|c|c|c|c|}
\hline \multicolumn{2}{|r|}{ Concentrations } & \multirow{2}{*}{$\begin{array}{l}\text { Protein Content } \\
\quad(\mu \mathrm{g} / \mathrm{g} \text { FW })\end{array}$} & \multirow{2}{*}{$\begin{array}{l}\text { SOD (UA mg } \\
\mathrm{g}^{-1} \text { Protein) }\end{array}$} & \multirow{2}{*}{\multicolumn{2}{|c|}{ POD (UA mg g ${ }^{-1}$ Protein) }} \\
\hline $\mathrm{Cr}(\mathrm{VI})(\mu \mathrm{M})$ & MEL (ppm) & & & & \\
\hline 0 & 0 & $18.70 \pm 0.45$ & $1.37 \pm 0.11$ & \multicolumn{2}{|c|}{$132.08 \pm 2.59$} \\
\hline 0 & 125 & $14.23 \pm 0.45$ & $1.70 \pm 0.47$ & \multicolumn{2}{|c|}{$132.35 \pm 2.09$} \\
\hline 0 & 250 & $15.90 \pm 0.30$ & $1.98 \pm 1.24$ & \multicolumn{2}{|c|}{$133.38 \pm 4.68$} \\
\hline 0 & 500 & $16.50 \pm 0.90$ & $2.09 \pm 0.05$ & \multicolumn{2}{|c|}{$146.67 \pm 1.27$} \\
\hline 250 & 0 & $9.60 \pm 0.30$ & $6.08 \pm 0.66$ & \multicolumn{2}{|c|}{$160.58 \pm 8.76$} \\
\hline 250 & 125 & $12.60 \pm 0.90$ & $7.71 \pm 0.08$ & \multicolumn{2}{|c|}{$184.77 \pm 9.37$} \\
\hline 250 & 250 & $15.73 \pm 0.45$ & $8.51 \pm 0.17$ & \multicolumn{2}{|c|}{$196.39 \pm 1.86$} \\
\hline 250 & 500 & $16.83 \pm 0.25$ & $9.22 \pm 0.09$ & \multicolumn{2}{|c|}{$241.91 \pm 36.27$} \\
\hline \multicolumn{2}{|c|}{ F-ratio Treatment $(1,16)$} & $135.06^{*}$ & $779.27^{*}$ & \multicolumn{2}{|c|}{$113.04^{*}$} \\
\hline \multirow{2}{*}{\multicolumn{2}{|c|}{$\begin{array}{c}\text { F-ratio Dose }(3,16) \\
\text { F-ratio Treatment } \times \text { Dose }_{(3,16)}\end{array}$}} & $43.05^{*}$ & $14.63^{*}$ & \multicolumn{2}{|c|}{$13.10^{*}$} \\
\hline & & $93.06^{*}$ & $5.56^{*}$ & \multirow{2}{*}{\multicolumn{2}{|c|}{$\begin{array}{l}6.05^{*} \\
38.97\end{array}$}} \\
\hline \multicolumn{2}{|c|}{$\begin{array}{c}\text { F-ratio Treatment } \times \text { Dose }(3,16) \\
\text { HSD }\end{array}$} & 1.57 & 1.51 & & \\
\hline \multirow{2}{*}{ Parameter } & \multirow{2}{*}{ MLR Equation } & \multicolumn{3}{|c|}{$\beta$-Regression Coefficient } & \multirow{2}{*}{$\begin{array}{c}\text { Multiple } \\
\text { Correlation }\end{array}$} \\
\hline & & $\mathrm{Cr}(\mathrm{VI})$ & (MEL) & $(\mathrm{Cr}(\mathrm{VI}) \times \mathrm{MEL})$ & \\
\hline Protein Content & $\begin{array}{l}\mathrm{Y}=16.79+-0.02 \mathrm{Cr}(\mathrm{VI})+-0.002 \\
(\mathrm{MEL})+7 \times 10^{-6}(\mathrm{Cr}(\mathrm{VI}) \times \mathrm{MEL})\end{array}$ & -1.17 & -0.14 & 1.05 & $0.86^{*}$ \\
\hline SOD & $\begin{array}{c}\mathrm{Y}=1.48+0.02 \mathrm{Cr}(\mathrm{VI})+0.001 \\
(\mathrm{MEL})+2 \times 10^{-6}(\mathrm{Cr}(\mathrm{VI}) \times \mathrm{MEL})\end{array}$ & 0.80 & 0.08 & 0.24 & $0.99^{*}$ \\
\hline POD & $\begin{array}{c}Y=129.53+0.12 \mathrm{Cr}(\mathrm{VI})+0.03 \\
(\mathrm{MEL})+0.0005(\mathrm{Cr}(\mathrm{VI}) \times \mathrm{MEL})\end{array}$ & 0.43 & 0.15 & 0.59 & $0.99^{*}$ \\
\hline
\end{tabular}


Table 4. Effect of $\mathrm{Cr}(\mathrm{VI})$, different concentrations of methanol extract of Rhododendron arboreum leaves (MEL), and their combinations on the activities of catalase (CAT), ascorbate peroxidase (APOX), and glutathione reductase (GR) enzymes in 7-day-old Vigna radiata seedlings. The values are the means of three replicates \pm SD. (standard deviation). Tukeys test performed and significance checked at ${ }^{*} p \leq 0.05$. The $\mathrm{F}$ ratio is the term in which ANOVA is represented; $\mathrm{Cr}(\mathrm{VI})=$ Dose, MEL treatments $=$ Treatment and combination of $\mathrm{Cr}(\mathrm{VI})$ and $\mathrm{MEL}=$ Dose $\times$ treatment.

\begin{tabular}{|c|c|c|c|c|c|}
\hline \multicolumn{2}{|r|}{ Concentrations } & \multirow{2}{*}{$\begin{array}{l}\text { CAT (UA mg } \\
\mathrm{g}^{-1} \text { Protein) }\end{array}$} & \multirow{2}{*}{\multicolumn{2}{|c|}{ APOX (UA mg g ${ }^{-1}$ Protein) }} & \multirow{2}{*}{$\begin{array}{l}\text { GR (UA mg } \\
\mathrm{g}^{-1} \text { Protein) }\end{array}$} \\
\hline $\mathrm{Cr}(\mathrm{VI})(\mu \mathrm{M})$ & MEL (ppm) & & & & \\
\hline 0 & 0 & $7.27 \pm 1.19$ & \multicolumn{2}{|c|}{$14.28 \pm 1.78$} & $27.01 \pm 3.62$ \\
\hline 0 & 125 & $7.56 \pm 0.65$ & \multicolumn{2}{|c|}{$14.76 \pm 4.32$} & $25.96 \pm 3.10$ \\
\hline 0 & 250 & $7.82 \pm 1.86$ & \multicolumn{2}{|c|}{$15.02 \pm 3.47$} & $28.20 \pm 2.26$ \\
\hline 0 & 500 & $8.40 \pm 1.50$ & \multicolumn{2}{|c|}{$16.61 \pm 2.82$} & $28.44 \pm 1.78$ \\
\hline 250 & 0 & $16.40 \pm 1.92$ & \multicolumn{2}{|c|}{$41.66 \pm 6.27$} & $47.16 \pm 3.71$ \\
\hline 250 & 125 & $17.54 \pm 2.19$ & \multicolumn{2}{|c|}{$53.04 \pm 2.61$} & $57.16 \pm 1.24$ \\
\hline 250 & 250 & $18.58 \pm 2.65$ & \multicolumn{2}{|c|}{$61.30 \pm 5.74$} & $61.44 \pm 3.56$ \\
\hline 250 & 500 & $23.22 \pm 2.06$ & \multicolumn{2}{|c|}{$80.94 \pm 2.72$} & $74.78 \pm 3.92$ \\
\hline & ratio Treatment $(1,16)$ & $217.87^{*}$ & \multicolumn{2}{|c|}{$725.75^{*}$} & $689.60^{*}$ \\
\hline & F-ratio Dose $(3,16)$ & $5.24^{*}$ & \multicolumn{2}{|c|}{$28.78^{*}$} & $24.07^{*}$ \\
\hline \multirow{2}{*}{\multicolumn{2}{|c|}{ F-ratio Treatment $\times$ Dose $(3,16)$}} & 2.76 & \multicolumn{2}{|c|}{$22.64^{*}$} & $18.55^{*}$ \\
\hline & & 5.24 & \multicolumn{2}{|c|}{11.33} & 8.63 \\
\hline \multirow{2}{*}{ Parameter } & \multirow{2}{*}{ MLR Equation } & \multicolumn{3}{|c|}{$\beta$-Regression Coefficient } & \multirow{2}{*}{$\begin{array}{l}\text { Multiple } \\
\text { Correlation }\end{array}$} \\
\hline & & Cr(VI) & (MEL) & $(\mathrm{Cr}(\mathrm{VI}) \times \mathrm{MEL})$ & \\
\hline CAT & $\begin{array}{c}\mathrm{Y}=7.27+0.03 \mathrm{Cr}(\mathrm{VI})+0.002 \\
(\mathrm{MEL})+5 \times 10^{-6}(\mathrm{Cr}(\mathrm{VI}) \times \mathrm{MEL})\end{array}$ & 0.73 & 0.07 & 0.33 & $0.99^{*}$ \\
\hline APOX & $\begin{array}{c}\mathrm{Y}=14.15+0.11 \mathrm{Cr}(\mathrm{VI})+0.004 \\
(\mathrm{MEL})+0.0003(\mathrm{Cr}(\mathrm{VI}) \times \mathrm{MEL})\end{array}$ & 0.57 & 0.03 & 0.51 & $0.99^{*}$ \\
\hline GR & $\begin{array}{c}\mathrm{Y}=26.54+0.08 \mathrm{Cr}(\mathrm{VI})+0.003 \\
(\mathrm{MEL})+0.0002(\mathrm{Cr}(\mathrm{VI}) \times \mathrm{MEL})\end{array}$ & 0.61 & 0.04 & 0.47 & $0.99^{*}$ \\
\hline
\end{tabular}

\subsection{Enzymatic Antioxidants}

The antioxidant enzymes were significantly altered by $\mathrm{Cr}(\mathrm{VI})$ exposure and supplementation with various concentrations of MEL. The superoxide dismutase (SOD) activity of 7-day-old Vigna radiata plants was enhanced from 1.37 (control) to $6.08 \mathrm{UA} \mathrm{mg} \mathrm{g}^{-1}$ protein under $\mathrm{Cr}(\mathrm{VI})$ treatment (Table 3). The combination of $\mathrm{Cr}(\mathrm{VI})$ and MEL further increased the SOD activity, and maximum enhancement to $9.22 \mathrm{UA} \mathrm{mg} \mathrm{g}^{-1}$ protein was noted in the case of $\mathrm{Cr}(\mathrm{VI}) \times 500 \mathrm{ppm}$ MEL. Similar trends were observed in POD (Table 3), CAT, APOX, GR (Table 4), DHAR, PPO, GST, and GPOX (Table 5) as Cr(VI) increased the enzyme activity, and co-application of MEL further enhanced the enzyme activity.

Two-way ANOVA analysis revealed that all the enzymes, SOD, POD, CAT, APOX, GR, DHAR, PPO, GST, and GPOX, had a statistically significant difference except in the case of the F ratio of the $\mathrm{Cr}(\mathrm{VI}) \times$ MEL interaction in CAT activity. The HSD values for SOD, POD, CAT, APOX, GR, DHAR, PPO, GST, and GPOX were noted to be 1.51, 38.97, 5.24, 11.33, 8.63, 7.59, 1.29, 6.79, and 1.63, respectively. The $\beta$ values in the MLR analysis for all the enzymes were positive for all the treatments, indicating the positive correlation.

\subsection{Non-Enzymatic Antioxidants}

The effect of individual and binary treatments of $\mathrm{Cr}(\mathrm{VI})$ and MEL on the contents of non-enzymatic antioxidants in 7-day-old Vigna radiata plants is presented in Table 6 . The ascorbic acid content was observed to be enhanced to $22.6 \mu \mathrm{g} \mathrm{g}^{-1} \mathrm{FW}$ in $\mathrm{Cr}(\mathrm{VI})$-treated plants in response to $11.97 \mu \mathrm{g} \mathrm{g}^{-1}$ FW in the control. Supplementation with $500 \mathrm{ppm}$ MEL to metal-stressed plants further elevated the ascorbic acid content to $49.05 \mu \mathrm{g} \mathrm{g}{ }^{-1} \mathrm{FW}$. The tocopherol content in the plants was increased with $\mathrm{Cr}(\mathrm{VI})\left(47.88 \mu \mathrm{g} \mathrm{g}^{-1} \mathrm{FW}\right)$ as compared to the control $\left(21.88 \mu \mathrm{g} \mathrm{g}^{-1} \mathrm{FW}\right)$. The content was further enhanced by the application of a combination of $\mathrm{Cr}(\mathrm{VI})$ and 125, 250 and 500 ppm MEL (62.52, 82.07, and $\left.98.99 \mu \mathrm{g} \mathrm{g}^{-1} \mathrm{FW}\right)$. The glutathione content was also observed to increase with $\mathrm{Cr}(\mathrm{VI})$ exposure to the plants (481.71 $\left.\mathrm{gg} \mathrm{g}^{-1} \mathrm{FW}\right)$ as compared to the control $\left(299.79 \mu \mathrm{g} \mathrm{g} \mathrm{g}^{-1} \mathrm{FW}\right)$. Priming of 
metal-stressed plants with MEL elevated the glutathione content even higher $\left(635.45 \mu \mathrm{g} \mathrm{g}^{-1} \mathrm{FW}\right.$ at $\mathrm{Cr}(\mathrm{VI}) \times 500 \mathrm{ppm} \mathrm{MEL})$. Ascorbic acid, tocopherol, and glutathione contents in 7-day-old Vigna radiata plants showed a statistically significant difference at $p \leq 0.05$ in the two-way ANOVA analysis, with HSD values of 3.42, 10.001, and 50.8, respectively. MLR analysis revealed that ascorbic acid, tocopherol, and glutathione increased (positive $\beta$ values) with $\mathrm{Cr}(\mathrm{VI})$ treatment and $\mathrm{Cr}(\mathrm{VI}) \times \mathrm{MEL}$ interactions.

Table 5. Effect of $\mathrm{Cr}(\mathrm{VI})$, different concentrations of methanol extract of Rhododendron arboreum leaves (MEL), and their combinations on the activities of dehydroascorbate reductase (DHAR), polyphenol oxydase (PPO), glutathione S-transferase (GST), and glutathione peroxidase (GPOX) enzymes in 7-day-old Vigna radiata seedlings. The values are the means of three replicates \pm SD. (standard deviation). Tukeys test performed and significance checked at ${ }^{*} p \leq 0.05$. The $\mathrm{F}$ ratio is the term in which ANOVA is represented; $\mathrm{Cr}(\mathrm{VI})=$ Dose, MEL treatments = Treatment and combination of $\mathrm{Cr}(\mathrm{VI})$ and $\mathrm{MEL}=$ Dose $\times$ treatment.

\begin{tabular}{|c|c|c|c|c|c|c|}
\hline \multicolumn{2}{|c|}{ Concentrations } & \multirow{2}{*}{$\begin{array}{l}\text { DHAR (UA mg } \\
\mathrm{g}^{-1} \text { Protein) }\end{array}$} & \multirow{2}{*}{$\begin{array}{l}\text { PPO (UA mg } \\
\mathrm{g}^{-1} \text { Protein) }\end{array}$} & \multirow{2}{*}{\multicolumn{2}{|c|}{ GST (UA mg g ${ }^{-1}$ Protein) }} & \multirow{2}{*}{$\begin{array}{l}\text { GPOX (UA mg } \\
\mathrm{g}^{-1} \text { Protein) }\end{array}$} \\
\hline $\operatorname{Cr}(\mathrm{VI})(\mu \mathrm{M})$ & MEL (ppm) & & & & & \\
\hline 0 & 0 & $26.95 \pm 2.57$ & $2.54 \pm 0.42$ & \multicolumn{2}{|c|}{$16.80 \pm 1.47$} & $16.41 \pm 0.34$ \\
\hline 0 & 125 & $25.71 \pm 2.85$ & $2.75 \pm 0.27$ & \multicolumn{2}{|c|}{$16.91 \pm 0.18$} & $17.75 \pm 0.39$ \\
\hline 0 & 250 & $27.80 \pm 2.65$ & $3.13 \pm 0.13$ & \multicolumn{2}{|c|}{$17.90 \pm 0.82$} & $17.82 \pm 0.13$ \\
\hline 0 & 500 & $30.57 \pm 0.75$ & $3.74 \pm 0.37$ & \multicolumn{2}{|c|}{$18.56 \pm 0.29$} & $17.98 \pm 0.34$ \\
\hline 250 & 0 & $54.28 \pm 2.85$ & $8.96 \pm 0.86$ & \multicolumn{2}{|c|}{$34.64 \pm 4.46$} & $26.09 \pm 0.67$ \\
\hline 250 & 125 & $69.62 \pm 1.08$ & $10.83 \pm 0.43$ & \multicolumn{2}{|c|}{$45.82 \pm 2.23$} & $27.65 \pm 0.79$ \\
\hline 250 & 250 & $78.92 \pm 4.32$ & $12.47 \pm 0.43$ & \multicolumn{2}{|c|}{$56.23 \pm 3.94$} & $26.49 \pm 0.21$ \\
\hline 250 & 500 & $92.65 \pm 2.67$ & $13.58 \pm 0.37$ & \multicolumn{2}{|c|}{$64.51 \pm 1.65$} & $28.67 \pm 1.05$ \\
\hline \multicolumn{2}{|c|}{ F-ratio Treatment $(1,16)$} & $1770.58^{*}$ & $2035.90^{*}$ & \multicolumn{2}{|c|}{$1115.51^{*}$} & $1708.56^{*}$ \\
\hline \multicolumn{2}{|c|}{ F-ratio Dose $(3,16)$} & $65.78^{*}$ & $45.55^{*}$ & \multicolumn{2}{|c|}{$49.10^{*}$} & $13.93^{*}$ \\
\hline \multirow{2}{*}{\multicolumn{2}{|c|}{$\begin{array}{c}\text { F-ratio Treatment } \times \text { Dose } \\
\text { HSD }\end{array}$}} & $44.24^{*}$ & $16.64^{*}$ & \multicolumn{2}{|c|}{$38.32^{*}$} & $3.09^{*}$ \\
\hline & & 7.59 & 1.29 & & 79 & 1.63 \\
\hline \multirow{2}{*}{ Parameter } & \multirow{2}{*}{\multicolumn{2}{|c|}{ MLR Equation }} & \multicolumn{3}{|c|}{$\beta$-Regression Coefficient } & \multirow{2}{*}{$\begin{array}{l}\text { Multiple } \\
\text { Correlation }\end{array}$} \\
\hline & & & Cr(VI) & (MEL) & $(\mathrm{Cr}(\mathrm{VI}) \times \mathrm{MEL})$ & \\
\hline DHAR & \multicolumn{2}{|c|}{$\begin{array}{c}\mathrm{Y}=25.9+0.12 \mathrm{Cr}(\mathrm{VI})+0.008(\mathrm{MEL}) \\
+0.0003(\mathrm{Cr}(\mathrm{VI}) \times \mathrm{MEL})\end{array}$} & 0.63 & 0.06 & 0.44 & $0.99^{*}$ \\
\hline $\mathrm{PPO}$ & \multicolumn{2}{|c|}{$\begin{aligned} \mathrm{Y}= & 2.5+0.02 \mathrm{Cr}(\mathrm{VI})+0.002(\mathrm{MEL}) \\
& \left.+3 \times 10^{-6} \mathrm{Cr}(\mathrm{VI}) \times \mathrm{MEL}\right)\end{aligned}$} & 0.79 & 0.10 & 0.25 & $0.99^{*}$ \\
\hline GST & \multicolumn{2}{|c|}{$\begin{array}{c}\mathrm{Y}=16.71+0.08 \mathrm{Cr}(\mathrm{VI})+0.003(\mathrm{MEL}) \\
+0.0002(\mathrm{Cr}(\mathrm{VI}) \times \mathrm{MEL})\end{array}$} & 0.56 & 0.03 & 0.51 & $0.99^{*}$ \\
\hline GPOX & \multicolumn{2}{|c|}{$\begin{aligned} \mathrm{Y}= & 16.92+0.03 \mathrm{Cr}(\mathrm{VI})+0.002(\mathrm{MEL}) \\
& +7 \times 10^{-7}(\mathrm{Cr}(\mathrm{VI}) \times \mathrm{MEL})\end{aligned}$} & 0.94 & 0.09 & 0.05 & $0.99^{*}$ \\
\hline
\end{tabular}

Table 6. Effect of $\mathrm{Cr}(\mathrm{VI})$, different concentrations of methanol extract of Rhododendron arboreum leaves (MEL), and their combinations on ascorbic acid, tocopherol, and glutathione content in 7-day-old Vigna radiata seedlings. The values are the means of three replicates \pm SD. (standard deviation). Tukeys test performed and significance checked at ${ }^{*} p \leq 0.05$. The $\mathrm{F}$ ratio is the term in which ANOVA is represented; $\mathrm{Cr}(\mathrm{VI})=$ Dose, MEL treatments $=$ Treatment and combination of $\mathrm{Cr}(\mathrm{VI})$ and MEL $=$ Dose $\times$ treatment.

\begin{tabular}{|c|c|c|c|c|c|c|}
\hline \multicolumn{2}{|c|}{ Concentrations } & \multirow{2}{*}{ Ascorbic Acid ( $\left.\mu \mathrm{g} \mathrm{g}^{-1} \mathrm{FW}\right)$} & \multirow{2}{*}{\multicolumn{2}{|c|}{ Tocopherol ( $\left.\mu \mathrm{g} \mathrm{g}^{-1} \mathrm{FW}\right)$}} & \multirow{2}{*}{\multicolumn{2}{|c|}{ Glutathione ( $\left.\mu \mathrm{g} \mathrm{g}^{-1} \mathrm{FW}\right)$}} \\
\hline $\operatorname{Cr}(\mathrm{VI})(\mu \mathrm{M})$ & MEL (ppm) & & & & & \\
\hline 0 & 0 & $11.97 \pm 0.36$ & \multicolumn{2}{|c|}{$21.88 \pm 1.90$} & \multicolumn{2}{|c|}{$299.79 \pm 7.68$} \\
\hline 0 & 125 & $15.80 \pm 0.72$ & \multicolumn{2}{|c|}{$30.42 \pm 1.02$} & \multicolumn{2}{|c|}{$333.10 \pm 8.87$} \\
\hline 0 & 250 & $19.70 \pm 1.88$ & \multicolumn{2}{|c|}{$32.22 \pm 0.62$} & \multicolumn{2}{|c|}{$384.35 \pm 20.33$} \\
\hline 0 & 500 & $26.45 \pm 0.49$ & \multicolumn{2}{|c|}{$40.76 \pm 4.12$} & \multicolumn{2}{|c|}{$443.28 \pm 16.01$} \\
\hline 250 & 0 & $22.60 \pm 0.41$ & \multicolumn{2}{|c|}{$47.88 \pm 0.69$} & \multicolumn{2}{|c|}{$481.71 \pm 11.74$} \\
\hline 250 & 125 & $28.45 \pm 1.27$ & \multicolumn{2}{|c|}{$62.52 \pm 0.04$} & \multicolumn{2}{|c|}{$407.41 \pm 20.33$} \\
\hline 250 & 250 & $39.30 \pm 0.65$ & \multicolumn{2}{|c|}{$82.07 \pm 4.85$} & \multicolumn{2}{|c|}{$520.15 \pm 29.10$} \\
\hline 250 & 500 & $49.05 \pm 2.23$ & \multicolumn{2}{|c|}{$98.99 \pm 7.33$} & \multicolumn{2}{|c|}{$635.45 \pm 19.34$} \\
\hline \multicolumn{2}{|c|}{ F-ratio Treatment ${ }_{(1,16)}$} & 1097.11* & \multicolumn{2}{|c|}{$828.52^{*}$} & \multicolumn{2}{|c|}{$396.82^{*}$} \\
\hline & & $326.84^{*}$ & \multicolumn{2}{|c|}{$107.15^{*}$} & \multicolumn{2}{|c|}{$107.27^{*}$} \\
\hline \multirow{2}{*}{\multicolumn{2}{|c|}{$\begin{array}{c}\text { F-ratio Treatment } \times \text { Dose }(3,16) \\
\text { HSD }\end{array}$}} & $32.78^{*}$ & \multicolumn{2}{|c|}{$27.12^{*}$} & \multicolumn{2}{|c|}{$13.43^{*}$} \\
\hline & & 3.42 & & & & \\
\hline \multirow{2}{*}{\multicolumn{2}{|c|}{ Parameter }} & MLR Equation & \multicolumn{3}{|c|}{$\beta$-Regression Coefficient } & \multirow{2}{*}{$\begin{array}{c}\text { Multiple } \\
\text { Correlation }\end{array}$} \\
\hline & & 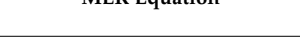 & $\mathrm{Cr}(\mathrm{VI})$ & (MEL) & $(\mathrm{Cr}(\mathrm{VI}) \times \mathrm{MEL})$ & \\
\hline \multicolumn{2}{|c|}{ Ascorbic Acid } & $\begin{array}{c}\mathrm{Y}=12.15+0.04 \mathrm{Cr}(\mathrm{VI})+0.02 \\
(\mathrm{MEL})+0.0001(\mathrm{Cr}(\mathrm{VI}) \times \mathrm{MEL})\end{array}$ & 0.47 & 0.46 & 0.37 & $0.99^{*}$ \\
\hline \multicolumn{2}{|c|}{ Tocopherol } & $\begin{array}{c}\mathrm{Y}=23.59+0.1 \mathrm{Cr}(\mathrm{VI})+0.03 \\
(\mathrm{MEL})+0.0003(\mathrm{Cr}(\mathrm{VI}) \times \mathrm{MEL})\end{array}$ & 0.52 & 0.25 & 0.45 & $0.99^{*}$ \\
\hline \multicolumn{2}{|c|}{ Glutathione } & $\begin{array}{c}\mathrm{Y}=301.33+0.51 \mathrm{Cr}(\mathrm{VI})+0.29 \\
(\mathrm{MEL})+0.0003(\mathrm{Cr}(\mathrm{VI}) \times \mathrm{MEL})\end{array}$ & 0.63 & 0.53 & 0.14 & $0.94^{*}$ \\
\hline
\end{tabular}




\subsection{Glutathione Imaging}

Tagging of glutathione in the roots of Vigna radiata was done by incubating the root sections in monochlorobimane dye (MCB) according to the method of Hartmann et al. [32] and the imaging was visualized using confocal microscopy. $\mathrm{MCB}$ produces a fluorescent adduct with glutathione. The intensity of the blue color indicates the measure of glutathione in roots. The intensity of the blue color indicates that the glutathione content increased with $\mathrm{Cr}(\mathrm{VI})$ stress as compared to the control plants. The amplification in the amount of blue color proves that co-application of MEL (500 ppm) along with $\mathrm{Cr}(\mathrm{VI})$ stress further increased the production of glutathione (Figure 1).
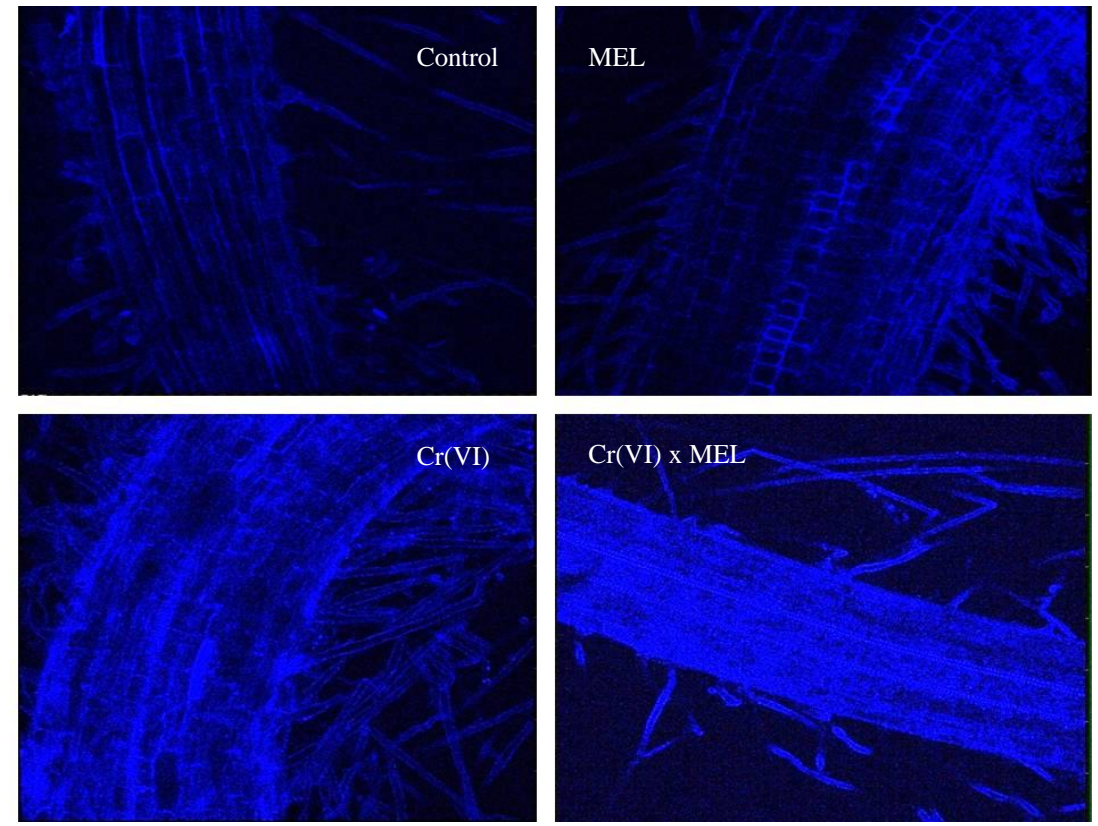

Figure 1. Effect of seed soaking treatment of methanol extract of Rhododendron arboreum leaves (MEL) on glutathione accumulation in Vigna radiata seedlings under $\mathrm{Cr}(\mathrm{VI})(250 \mu \mathrm{M})$ stress.

\subsection{Polyphenol Content}

Qualitative as well as quantitative analysis of the plant samples for polyphenolic compounds was carried out using ultra high-performance liquid chromatography (UHPLC). Five polyphenols, namely gallic acid, chlorogenic acid, caffeic acid, catechin, and coumaric acid, were found to be present in the plants. A comparative change in the polyphenolic contents of Vigna radiata plants grown under $\mathrm{Cr}(\mathrm{VI})$ exposure and the combination of $\mathrm{Cr}(\mathrm{VI}) \times$ MEL treatments is represented in Table 7 . The contents of all the polyphenols increased with $\mathrm{Cr}(\mathrm{VI})$ stress. The supplementation of MEL to $\mathrm{Cr}(\mathrm{VI})$-exposed plants further enhanced the polyphenol content and the maximum increase was observed in the case of the combination of $\mathrm{Cr}(\mathrm{VI}) \times 500 \mathrm{ppm}$ MEL. Two-way ANOVA analysis of the polyphenols revealed a statistically significant difference. However, in case of catechin, the interaction of $\mathrm{Cr}(\mathrm{VI}) \times \mathrm{MEL}$ treatment was noted to be non-significant. The $\beta$ values from MLR analysis depict that gallic acid was positively affected by $\mathrm{Cr}(\mathrm{VI})$ treatment and negatively affected by co-application of $\mathrm{Cr}(\mathrm{VI}) \times \mathrm{MEL}$, whereas chlorogenic acid, caffeic acid, catechin, and coumaric acid were positively affected by the $\mathrm{Cr}(\mathrm{VI})$ and $\mathrm{Cr}(\mathrm{VI}) \times$ MEL treatments.

\subsection{Amino Acid Content}

The total amino acids content decreased to $591.47 \mu \mathrm{g} \mathrm{g}^{-1} \mathrm{FW}$ with $\mathrm{Cr}(\mathrm{VI})$ stress from $2504.69 \mu \mathrm{g} \mathrm{G}^{-1} \mathrm{FW}$ in control plants. MEL recovered the amino acid content in the $\mathrm{Cr}(\mathrm{VI})$-stressed plants, and the maximum recovery was observed to be $2208.89 \mathrm{\mu g} \mathrm{g}^{-1} \mathrm{FW}$ in plants given the combination of 500 ppm MEL with Cr(VI). In total, 17 amino acids, namely aspartic acid, glutamine, $\beta$-alanine, 
lysine, glutamic acid, asparagines, serine, isoleucine, glycine, threonine, citrulline, arginine, GABA (gamma-aminobutyric acid ), cystine, ornithine, proline, and methionine, were found to be present in the plant samples. The variations in the contents of these amino acids due to treatment with $\mathrm{Cr}(\mathrm{VI})$ and MEL alone or in combination with each other are presented in Tables 8-11.

Table 7. Effect of $\mathrm{Cr}(\mathrm{VI})$, different concentrations of methanol extract of Rhododendron arboreum leaves (MEL), and their combinations on polyphenol contents in 7-day-old Vigna radiata seedlings. The values are the means of three replicates \pm S.D. (standard deviation). Tukeys test performed and significance checked at ${ }^{*} p \leq 0.05$. The $\mathrm{F}$ ratio is the term in which ANOVA is represented; $\mathrm{Cr}(\mathrm{VI})=\mathrm{Dose}$, MEL treatments $=$ Treatment and combination of $\mathrm{Cr}(\mathrm{VI})$ and $\mathrm{MEL}=$ Dose $\times$ treatment.

\begin{tabular}{|c|c|c|c|c|c|c|c|}
\hline \multicolumn{2}{|c|}{ Concentrations } & \multirow{2}{*}{ Gallic Acid ( $\left.\mu \mathrm{g} \mathrm{g}^{-1} \mathrm{FW}\right)$} & \multirow{2}{*}{$\begin{array}{l}\text { ChlorogenicAcid } \\
\quad\left(\mu \mathrm{g} \mathrm{g}^{-1} \text { FW) }\right.\end{array}$} & \multirow{2}{*}{$\begin{array}{l}\text { Caffeic Acid } \\
\left(\mu \mathrm{g} \mathrm{g}^{-1} \text { FW }\right)\end{array}$} & \multirow{2}{*}{\multicolumn{2}{|c|}{ Catechin $\left(\mu \mathrm{g} \mathrm{g}^{-1} \mathrm{FW}\right)$}} & \multirow{2}{*}{$\begin{array}{c}\text { Coumaric Acid } \\
\left(\mu \mathrm{g} \mathrm{g}^{-1} \text { FW }\right)\end{array}$} \\
\hline $\operatorname{Cr}(\mathrm{VI})(\mu \mathrm{M})$ & MEL (ppm) & & & & & & \\
\hline 0 & 0 & $9.60 \pm 1.40$ & $1.74 \pm 0.05$ & $0.10 \pm 0.002$ & \multicolumn{2}{|c|}{$263.80 \pm 16.15$} & $0.18 \pm 0.004$ \\
\hline 0 & 125 & $9.87 \pm 0.60$ & $1.64 \pm 0.01$ & $0.15 \pm 0.008$ & \multicolumn{2}{|c|}{$268.03 \pm 49.93$} & $0.16 \pm 0.006$ \\
\hline 0 & 250 & $10.46 \pm 1.06$ & $1.74 \pm 0.03$ & $0.16 \pm 0.003$ & \multicolumn{2}{|c|}{$282.89 \pm 55.04$} & $0.18 \pm 0.006$ \\
\hline 0 & 500 & $13.57 \pm 0.91$ & $1.81 \pm 0.03$ & $0.18 \pm 0.004$ & \multicolumn{2}{|c|}{$287.84 \pm 9.55$} & $0.21 \pm 0.006$ \\
\hline 250 & 0 & $16.05 \pm 0.43$ & $4.60 \pm 0.11$ & $0.94 \pm 0.009$ & \multicolumn{2}{|c|}{$331.08 \pm 53.67$} & $0.44 \pm 0.020$ \\
\hline 250 & 125 & $13.22 \pm 0.71$ & $3.21 \pm 0.64$ & $0.84 \pm 0.01$ & \multicolumn{2}{|c|}{$422.96 \pm 10.10$} & $0.35 \pm 0.010$ \\
\hline 250 & 250 & $15.18 \pm 0.61$ & $4.22 \pm 0.25$ & $0.96 \pm 0.04$ & \multicolumn{2}{|c|}{$430.51 \pm 20.83$} & $0.59 \pm 0.020$ \\
\hline 250 & 500 & $17.51 \pm 0.50$ & $5.26 \pm 0.12$ & $1.24 \pm 0.16$ & \multicolumn{2}{|c|}{$447.50 \pm 35.40$} & $0.74 \pm 0.050$ \\
\hline F-ratio $\mathrm{Tr}$ & nent $(116)$ & $185.09^{*}$ & $618.21^{*}$ & $124.54^{*}$ & \multicolumn{2}{|c|}{$79.75^{*}$} & $1207.79^{*}$ \\
\hline F-ratio & $e_{(3,16)}$ & $24.66^{*}$ & $19.73^{*}$ & $16.50^{*}$ & \multicolumn{2}{|r|}{$4.35^{*}$} & $87.41^{*}$ \\
\hline \multirow{2}{*}{\multicolumn{2}{|c|}{$\begin{array}{c}\text { F-ratio Treatment } \times \text { Dose }(3,16) \\
\text { HSD }\end{array}$}} & $3.93^{*}$ & $14.41^{*}$ & $10.08^{*}$ & \multicolumn{2}{|r|}{2.17} & $59.07^{*}$ \\
\hline & & 2.35 & 0.72 & 0.16 & \multicolumn{2}{|r|}{102.71} & 0.06 \\
\hline \multirow{2}{*}{\multicolumn{2}{|c|}{ Parameter }} & \multirow{2}{*}{\multicolumn{2}{|c|}{ MLR Equation }} & \multicolumn{3}{|c|}{$\beta$-Regression Coefficient } & Multiple \\
\hline & & & & Cr(VI) & (MEL) & $(\mathrm{Cr}(\mathrm{VI}) \times \mathrm{MEL})$ & Correlation \\
\hline \multicolumn{2}{|c|}{ Gallic Acid } & \multicolumn{2}{|c|}{$\begin{array}{c}\mathrm{Y}=9.08+0.02 \mathrm{Cr}(\mathrm{VI})+0.008(\mathrm{MEL})+1 \times 10^{-6} \\
(\mathrm{Cr}(\mathrm{VI}) \times \mathrm{MEL})\end{array}$} & 0.96 & 0.54 & -0.2 & $0.93^{*}$ \\
\hline \multicolumn{2}{|c|}{ Chlorogenic Acid } & \multicolumn{2}{|c|}{$\begin{aligned} \mathrm{Y}=1.69+ & 0.008 \mathrm{Cr}(\mathrm{VI})+0.0002(\mathrm{MEL})+8 \\
& \times 10^{-7}(\mathrm{Cr}(\mathrm{VI}) \times \mathrm{MEL})\end{aligned}$} & 0.76 & 0.02 & 0.24 & $0.94^{*}$ \\
\hline \multicolumn{2}{|c|}{ Caffeic Acid } & \multicolumn{2}{|c|}{$\begin{array}{c}\mathrm{Y}=0.12+0.002 \mathrm{Cr}(\mathrm{VI})+0.0001(\mathrm{MEL})+ \\
2 \times 10^{-7}(\mathrm{Cr}(\mathrm{VI}) \times \mathrm{MEL})\end{array}$} & 0.83 & 0.06 & 0.21 & $0.99^{*}$ \\
\hline \multicolumn{2}{|c|}{ Catechin } & \multicolumn{2}{|c|}{$\begin{array}{c}\mathrm{Y}=264.5+0.39 \mathrm{Cr}(\mathrm{VI})+0.05(\mathrm{MEL})+0.0006 \\
(\mathrm{Cr}(\mathrm{VI}) \times \mathrm{MEL})\end{array}$} & 0.67 & 0.12 & 0.34 & $0.96^{*}$ \\
\hline \multicolumn{2}{|c|}{ Coumaric Acid } & \multicolumn{2}{|c|}{$\begin{aligned} \mathrm{Y}=0.17+ & 0.0008 \mathrm{Cr}(\mathrm{VI})+7 \times 10^{-6}(\mathrm{MEL})+3 \\
& \times 10^{-7}(\mathrm{Cr}(\mathrm{VI}) \times \mathrm{MEL})\end{aligned}$} & 0.51 & 0.05 & 0.53 & $0.96^{*}$ \\
\hline
\end{tabular}

Table 8. Effect of $\mathrm{Cr}(\mathrm{VI})$, different concentrations of methanol extract of Rhododendron arboreum leaves (MEL), and their combinations on aspartic acid, glutamine, $\beta$-alanine, and lysine contents in 7 -day-old Vigna radiata seedlings. The values are the means of three replicates \pm SD. (standard deviation). Tukeys test performed and significance checked at ${ }^{*} p \leq 0.05$. The F ratio is the term in which ANOVA is represented; $\mathrm{Cr}(\mathrm{VI})=$ Dose, MEL treatments $=$ Treatment and combination of $\mathrm{Cr}(\mathrm{VI})$ and MEL $=$ Dose $\times$ treatment.

\begin{tabular}{|c|c|c|c|c|c|c|}
\hline \multicolumn{2}{|c|}{ Concentrations } & \multirow{2}{*}{ Aspartic Acid ( $\left.\mu \mathrm{g} \mathrm{g}^{-1} \mathrm{FW}\right)$} & \multirow{2}{*}{$\begin{array}{l}\text { Glutamine } \\
\left(\mu \mathrm{g} \mathrm{g}^{-1} \mathrm{FW}\right)\end{array}$} & \multirow{2}{*}{\multicolumn{2}{|c|}{$\beta$-Alanine ( $\left.\mu \mathrm{g} \mathrm{g}^{-1} \mathrm{FW}\right)$}} & \multirow{2}{*}{$\begin{array}{c}\text { Lysine } \\
\left(\mu \mathrm{g} \mathrm{g}^{-1} \text { FW) }\right.\end{array}$} \\
\hline $\mathrm{Cr}(\mathrm{VI})(\mu \mathrm{M})$ & MEL (ppm) & & & & & \\
\hline 0 & 0 & $79.00 \pm 0.85$ & $40.61 \pm 0.35$ & \multicolumn{2}{|c|}{$168.83 \pm 0.86$} & $35.11 \pm 0.48$ \\
\hline 0 & 125 & $45.71 \pm 2.43$ & $37.30 \pm 0.46$ & \multicolumn{2}{|c|}{$90.79 \pm 0.34$} & $17.81 \pm 0.62$ \\
\hline 0 & 250 & $63.18 \pm 0.39$ & $38.45 \pm 0.50$ & \multicolumn{2}{|c|}{$101.34 \pm 0.51$} & $18.85 \pm 0.85$ \\
\hline 0 & 500 & $74.18 \pm 0.68$ & $39.72 \pm 0.98$ & \multicolumn{2}{|c|}{$114.37 \pm 0.48$} & $20.73 \pm 0.81$ \\
\hline 250 & 0 & $32.16 \pm 0.60$ & $8.82 \pm 1.12$ & \multicolumn{2}{|c|}{$35.96 \pm 0.98$} & $18.54 \pm 1.44$ \\
\hline 250 & 125 & $73.39 \pm 0.57$ & $30.08 \pm 0.71$ & \multicolumn{2}{|c|}{$115.62 \pm 0.22$} & $23.70 \pm 1.03$ \\
\hline 250 & 250 & $75.90 \pm 0.13$ & $36.40 \pm 0.51$ & \multicolumn{2}{|c|}{$124.54 \pm 1.40$} & $29.54 \pm 0.78$ \\
\hline 250 & 500 & $78.04 \pm 0.51$ & $39.60 \pm 0.57$ & \multicolumn{2}{|c|}{$164.09 \pm 0.67$} & $30.84 \pm 1.14$ \\
\hline \multicolumn{2}{|c|}{ F-ratio Treatment ${ }_{(1,16)}$} & 2.43 & $1295.79^{*}$ & \multicolumn{2}{|c|}{$769.44^{*}$} & $43.96^{*}$ \\
\hline \multicolumn{2}{|c|}{ F-ratio Dose $(3,16)$} & $509.11^{*}$ & $529.81^{*}$ & \multicolumn{2}{|c|}{$2956.89^{*}$} & $48.24^{*}$ \\
\hline \multirow{2}{*}{\multicolumn{2}{|c|}{$\begin{array}{c}\text { F-ratio Treatment } \times \text { Dose }(3,16) \\
\text { HSD }\end{array}$}} & $1520.74^{*}$ & $655.19^{*}$ & \multicolumn{2}{|c|}{$17456.18^{*}$} & $285.57^{*}$ \\
\hline & & 2.87 & 1.98 & & .19 & 2.64 \\
\hline \multirow{2}{*}{\multicolumn{2}{|c|}{ Parameter }} & \multirow{2}{*}{ MLR equation } & \multicolumn{3}{|c|}{$\beta$-Regression Coefficient } & \multirow{2}{*}{$\begin{array}{l}\text { Multiple } \\
\text { correlation }\end{array}$} \\
\hline & & & $\mathrm{Cr}(\mathrm{VI})$ & (MEL) & $(\mathrm{Cr}(\mathrm{VI}) \times \mathrm{MEL})$ & \\
\hline \multicolumn{2}{|c|}{ Aspartic Acid } & $\begin{array}{l}\mathrm{Y}=63.48+-0.06 \mathrm{Cr}(\mathrm{VI})+0.009 \\
(\mathrm{MEL})+0.0003(\mathrm{Cr}(\mathrm{VI}) \times \mathrm{MEL})\end{array}$ & -0.17 & 0.1 & 0.7 & 0.62 \\
\hline \multicolumn{2}{|c|}{ Glutamine } & $\begin{array}{c}\mathrm{Y}=39.03+-0.08 \mathrm{Cr}(\mathrm{VI})+5 \times 10^{-6} \\
(\mathrm{MEL})+0.0002(\mathrm{Cr}(\mathrm{VI}) \times \mathrm{MEL})\end{array}$ & -1.12 & -0.0009 & 0.94 & $0.88^{*}$ \\
\hline \multicolumn{2}{|c|}{$\beta$-Alanine } & $\begin{array}{c}\mathrm{Y}=135.01+-0.3 \mathrm{Cr}(\mathrm{VI})+-0.074 \\
(\mathrm{MEL})+0.0012(\mathrm{Cr}(\mathrm{VI}) \times \mathrm{MEL})\end{array}$ & -0.95 & -0.34 & 1.31 & $0.8^{*}$ \\
\hline \multicolumn{2}{|c|}{ Lysine } & $\begin{array}{l}Y=27.81+-0.03 \mathrm{Cr}(\mathrm{VI})+-0.02 \\
(\mathrm{MEL})+0.0002(\mathrm{Cr}(\mathrm{VI}) \times \mathrm{MEL})\end{array}$ & -0.6 & -0.64 & 1.26 & $0.71^{*}$ \\
\hline
\end{tabular}


Table 9. Effect of $\mathrm{Cr}(\mathrm{VI})$, different concentrations of methanol extract of Rhododendron arboreum leaves (MEL), and their combinations on glutamic acid, asparagine, serine, and isoleucine contents in 7-day-old Vigna radiata seedlings. The values are the means of three replicates \pm S.D. (standard deviation). Tukeys test performed and significance checked at ${ }^{*} p \leq 0.05$. The $\mathrm{F}$ ratio is the term in which ANOVA is represented; $\mathrm{Cr}(\mathrm{VI})=$ Dose, MEL treatments $=$ Treatment and combination of $\mathrm{Cr}(\mathrm{VI})$ and MEL $=$ Dose $\times$ treatment.

\begin{tabular}{|c|c|c|c|c|c|c|}
\hline \multicolumn{2}{|c|}{ Concentrations } & \multirow{2}{*}{ Glutamic Acid ( $\left.\mu \mathrm{g} \mathrm{g}^{-1} \mathrm{FW}\right)$} & \multirow{2}{*}{$\begin{array}{l}\text { Asparagine } \\
\left(\mu \mathrm{g} \mathrm{g}^{-1} \mathrm{FW}\right)\end{array}$} & \multirow{2}{*}{\multicolumn{2}{|c|}{ Serine $\left(\mu \mathrm{g} \mathrm{g}^{-1} \mathrm{FW}\right)$}} & \multirow{2}{*}{$\begin{array}{l}\text { Isoleucine } \\
\left(\mu \mathrm{g} \mathrm{g}^{-1} \mathrm{FW}\right)\end{array}$} \\
\hline $\mathrm{Cr}(\mathrm{VI})(\mu \mathrm{M})$ & MEL (ppm) & & & & & \\
\hline 0 & 0 & $29.83 \pm 0.76$ & $1134.65 \pm 48.39$ & \multicolumn{2}{|c|}{$10.01 \pm 0.38$} & $174.95 \pm 1.75$ \\
\hline 0 & 125 & $15.84 \pm 0.79$ & $443.42 \pm 9.80$ & \multicolumn{2}{|c|}{$1.23 \pm 0.09$} & $65.96 \pm 0.77$ \\
\hline 0 & 250 & $18.80 \pm 0.87$ & $652.13 \pm 14.26$ & \multicolumn{2}{|c|}{$1.94 \pm 0.13$} & $68.31 \pm 0.60$ \\
\hline 0 & 500 & $22.84 \pm 0.70$ & $686.02 \pm 12.23$ & \multicolumn{2}{|c|}{$3.68 \pm 0.56$} & $86.11 \pm 1.10$ \\
\hline 250 & 0 & $8.65 \pm 1.31$ & $355.18 \pm 34.14$ & \multicolumn{2}{|c|}{$0.58 \pm 0.15$} & $13.75 \pm 3.03$ \\
\hline 250 & 125 & $25.35 \pm 0.71$ & $824.64 \pm 26.16$ & \multicolumn{2}{|c|}{$6.15 \pm 0.06$} & $87.03 \pm 1.25$ \\
\hline 250 & 250 & $27.43 \pm 0.52$ & $875.57 \pm 16.85$ & \multicolumn{2}{|c|}{$6.98 \pm 0.12$} & $104.83 \pm 0.99$ \\
\hline 250 & 500 & $28.47 \pm 0.50$ & $974.98 \pm 22.29$ & \multicolumn{2}{|c|}{$7.84 \pm 0.89$} & $146.25 \pm 16.09$ \\
\hline \multicolumn{2}{|c|}{ F-ratio Treatment $_{(1,16)}$} & 3.83 & $7.20^{*}$ & \multicolumn{2}{|c|}{$49.47^{*}$} & $20.52^{*}$ \\
\hline \multicolumn{2}{|c|}{ F-ratio Dose $(3,16)$} & $73.33^{*}$ & $58.91^{*}$ & \multicolumn{2}{|c|}{$30.23^{*}$} & $49.36^{*}$ \\
\hline \multirow{2}{*}{\multicolumn{2}{|c|}{$\begin{array}{c}\text { F-ratio Treatment } \times \text { Dose }_{(3,16)} \\
\text { HSD }\end{array}$}} & $489.49^{*}$ & $651.33^{*}$ & \multicolumn{2}{|c|}{$451.69^{*}$} & $447.64^{*}$ \\
\hline & & 2.29 & 73.65 & \multicolumn{2}{|c|}{1.153} & 16.62 \\
\hline \multirow{2}{*}{\multicolumn{2}{|c|}{ Parameter }} & \multirow{2}{*}{ MLR equation } & \multicolumn{3}{|c|}{$\beta$-Regression Coefficient } & \multirow{2}{*}{$\begin{array}{c}\text { Multiple } \\
\text { correlation }\end{array}$} \\
\hline & & & $\mathrm{Cr}(\mathrm{VI})$ & (MEL) & $(\mathrm{Cr}(\mathrm{VI}) \times \mathrm{MEL})$ & \\
\hline \multicolumn{2}{|c|}{ Glutamic Acid } & $\begin{array}{c}\mathrm{Y}=23.43+-0.03 \mathrm{Cr}(\mathrm{VI})+-0.007 \\
(\mathrm{MEL})+0.0002(\mathrm{Cr}(\mathrm{VI}) \times \mathrm{MEL})\end{array}$ & -0.61 & -0.19 & 1.02 & 0.66 \\
\hline \multicolumn{2}{|c|}{ Asparagine } & $\begin{array}{c}\mathrm{Y}=851.39+-1.31 \mathrm{Cr}(\mathrm{VI})+-0.55 \\
(\mathrm{MEL})+0.0065(\mathrm{Cr}(\mathrm{VI}) \times \mathrm{MEL})\end{array}$ & -0.66 & -0.42 & 1.13 & 0.64 \\
\hline \multicolumn{2}{|c|}{ Serine } & $\begin{array}{c}\mathrm{Y}=6.15+-0.01 \mathrm{Cr}(\mathrm{VI})+-0.009 \\
(\mathrm{MEL})+9 \times 10^{-6}(\mathrm{Cr}(\mathrm{VI}) \times \mathrm{MEL})\end{array}$ & -0.54 & -0.5 & 1.13 & 0.64 \\
\hline \multicolumn{2}{|c|}{ Isoleucine } & $\begin{array}{l}\mathrm{Y}=127.8+-0.37 \mathrm{Cr}(\mathrm{VI})+-0.13 \\
(\mathrm{MEL})+0.001(\mathrm{Cr}(\mathrm{VI}) \times \mathrm{MEL})\end{array}$ & -0.99 & -0.52 & 1.37 & $0.78^{*}$ \\
\hline
\end{tabular}

Table 10. Effect of $\mathrm{Cr}(\mathrm{VI})$, different concentrations of methanol extract of Rhododendron arboreum leaves (MEL), and their combinations on glycine, threonine, citrulline, arginine, and gamma-aminobutyric acid (GABA) contents in 7-day-old Vigna radiata seedlings. The values are the means of three replicates \pm SD. (standard deviation). Tukeys test performed and significance checked at ${ }^{*} p \leq 0.05$. The $\mathrm{F}$ ratio is the term in which ANOVA is represented; $\mathrm{Cr}(\mathrm{VI})=$ Dose, MEL treatments = Treatment and combination of $\mathrm{Cr}(\mathrm{VI})$ and $\mathrm{MEL}=$ Dose $\times$ treatment.

\begin{tabular}{|c|c|c|c|c|c|c|c|}
\hline \multicolumn{2}{|c|}{ Concentrations } & \multirow{2}{*}{ Glycine ( $\left.\mu \mathrm{g} \mathrm{g}^{-1} \mathrm{FW}\right)$} & \multirow{2}{*}{$\begin{array}{l}\text { Threonine } \\
\left(\mu \mathrm{g} \mathrm{g}^{-1} \mathrm{FW}\right)\end{array}$} & \multirow{2}{*}{$\begin{array}{c}\text { Citrulline } \\
\left(\mu \mathrm{g} \mathrm{g}^{-1} \mathrm{FW}\right)\end{array}$} & \multirow{2}{*}{\multicolumn{2}{|c|}{ Arginine $\left(\mu \mathrm{g} \mathrm{g}^{-1} \mathrm{FW}\right)$}} & \multirow{2}{*}{$\begin{array}{c}\text { GABA } \\
\left(\mu \mathrm{g} \mathrm{g}^{-1} \mathrm{FW}\right)\end{array}$} \\
\hline $\mathrm{Cr}(\mathrm{VI})(\mu \mathrm{M})$ & MEL (ppm) & & & & & & \\
\hline 0 & 0 & $9.47 \pm 0.56$ & $6.39 \pm 0.68$ & $22.55 \pm 1.18$ & \multicolumn{2}{|c|}{$647.02 \pm 12.48$} & $5.009 \pm 0.26$ \\
\hline 0 & 125 & $4.64 \pm 0.40$ & $2.72 \pm 0.22$ & $10.97 \pm 0.81$ & \multicolumn{2}{|c|}{$97.11 \pm 5.87$} & $1.89 \pm 0.04$ \\
\hline 0 & 250 & $5.48 \pm 0.46$ & $3.38 \pm 0.72$ & $12.60 \pm 0.50$ & \multicolumn{2}{|c|}{$164.57 \pm 6.72$} & $2.47 \pm 0.40$ \\
\hline 0 & 500 & $6.07 \pm 0.76$ & $3.81 \pm 0.06$ & $15.61 \pm 1.07$ & \multicolumn{2}{|c|}{$181.85 \pm 6.55$} & $3.06 \pm 0.67$ \\
\hline 250 & 0 & $3.58 \pm 0.32$ & $1.37 \pm 0.42$ & $4.91 \pm 0.75$ & \multicolumn{2}{|c|}{$78.43 \pm 7.27$} & $1.18 \pm 0.37$ \\
\hline 250 & 125 & $6.77 \pm 0.37$ & $3.72 \pm 0.09$ & $15.93 \pm 0.82$ & \multicolumn{2}{|c|}{$311.96 \pm 49.42$} & $2.89 \pm 0.12$ \\
\hline 250 & 250 & $7.25 \pm 0.29$ & $4.22 \pm 0.27$ & $19.47 \pm 0.62$ & \multicolumn{2}{|c|}{$466.28 \pm 18.01$} & $3.49 \pm 0.43$ \\
\hline 250 & 500 & $8.14 \pm 0.96$ & $4.86 \pm 0.76$ & $20.94 \pm 0.52$ & \multicolumn{2}{|c|}{$575.68 \pm 11.60$} & $4.16 \pm 0.83$ \\
\hline \multicolumn{2}{|c|}{ F-ratio Treatment $(1,16)$} & 0.006 & $7.06^{*}$ & 0.12 & \multicolumn{2}{|c|}{$108.4^{*}$} & 0.84 \\
\hline F-ratio & $\operatorname{se}_{(3,16)}$ & $6.24^{*}$ & $5.26^{*}$ & $45.23^{*}$ & \multicolumn{2}{|c|}{$91.77^{*}$} & $6.97^{*}$ \\
\hline \multicolumn{2}{|c|}{ F-ratio Treatment $\times$ Dose $(3,16)$} & $73.37^{*}$ & $56.22^{*}$ & $305.2^{*}$ & \multicolumn{2}{|c|}{$725.5^{*}$} & $41.19^{*}$ \\
\hline \multicolumn{2}{|c|}{ HSD } & 1.59 & 1.38 & 2.32 & \multicolumn{2}{|c|}{56.87} & 1.31 \\
\hline \multirow{2}{*}{\multicolumn{2}{|c|}{ Parameter }} & \multirow{2}{*}{\multicolumn{2}{|c|}{ MLR Equation }} & \multicolumn{3}{|c|}{$\beta$-Regression Coefficient } & Multiple \\
\hline & & & & $\mathrm{Cr}(\mathrm{VI})$ & (MEL) & $(\mathrm{Cr}(\mathrm{VI}) \times \mathrm{MEL})$ & Correlation \\
\hline \multicolumn{2}{|c|}{ Glycine } & \multicolumn{2}{|c|}{$\begin{aligned} \mathrm{Y}=7.42+ & -0.01 \mathrm{Cr}(\mathrm{VI})+-0.005(\mathrm{MEL})+5 \\
& \times 10^{-6}(\mathrm{Cr}(\mathrm{VI}) \times \mathrm{MEL})\end{aligned}$} & -0.77 & -0.47 & 1.2 & 0.67 \\
\hline \multicolumn{2}{|c|}{ Threonine } & \multicolumn{2}{|c|}{$\begin{aligned} \mathrm{Y}=4.84+ & -0.01 \mathrm{Cr}(\mathrm{VI})+-0.003(\mathrm{MEL})+4 \\
& \times 10^{-6}(\mathrm{Cr}(\mathrm{VI}) \times \mathrm{MEL})\end{aligned}$} & -0.96 & -0.46 & 1.19 & 0.7 \\
\hline \multicolumn{2}{|c|}{ Citrulline } & \multicolumn{2}{|c|}{$\begin{aligned} \mathrm{Y}=17.32+-0.03 \mathrm{Cr}(\mathrm{VI})+-0.009(\mathrm{MEL}) & \\
& +0.0001(\mathrm{Cr}(\mathrm{VI}) \times \mathrm{MEL})\end{aligned}$} & -0.76 & -0.29 & 1.17 & $0.72^{*}$ \\
\hline \multicolumn{2}{|c|}{ Arginine } & \multicolumn{2}{|c|}{$\begin{array}{c}\mathrm{Y}=423.61+-1.09 \mathrm{Cr}(\mathrm{VI})+-0.69(\mathrm{MEL})+0.006 \\
(\mathrm{Cr}(\mathrm{VI}) \times \mathrm{MEL})\end{array}$} & -0.65 & -0.61 & 1.34 & $0.76^{*}$ \\
\hline \multicolumn{2}{|c|}{ GABA } & \multicolumn{2}{|c|}{$\begin{aligned} \mathrm{Y}=3.64+ & -0.008 \mathrm{Cr}(\mathrm{VI})+-0.002(\mathrm{MEL})+3 \\
& \times 10^{-6}(\mathrm{Cr}(\mathrm{VI}) \times \mathrm{MEL})\end{aligned}$} & -0.83 & -0.39 & 1.18 & 0.69 \\
\hline
\end{tabular}


Table 11. Effect of $\mathrm{Cr}(\mathrm{VI})$, different concentrations of methanol extract of Rhododendron arboreum leaves (MEL), and their combinations on cystine, ornithine, proline, methionine, and total amino acid contents in 7-day-old Vigna radiata seedlings. The values are the means of three replicates \pm SD. (standard deviation). Tukeys test performed and significance checked at ${ }^{*} p \leq 0.05$. The $\mathrm{F}$ ratio is the term in which ANOVA is represented; $\mathrm{Cr}(\mathrm{VI})=$ Dose, MEL treatments = Treatment and combination of $\mathrm{Cr}(\mathrm{VI})$ and $\mathrm{MEL}=$ Dose $\times$ treatment.

\begin{tabular}{|c|c|c|c|c|c|c|c|}
\hline \multicolumn{2}{|c|}{ Concentrations } & \multirow{2}{*}{ Cystine ( $\mu \mathrm{g} \mathrm{g}^{-1}$ FW) } & \multirow{2}{*}{$\begin{array}{c}\text { Ornithine } \\
\left(\mu \mathrm{g} \mathrm{g}^{-1} \mathrm{FW}\right)\end{array}$} & \multirow{2}{*}{$\begin{array}{c}\begin{array}{c}\text { Proline } \\
\left(\mu \mathrm{g} \mathrm{g}^{-1} \mathrm{FW}\right)\end{array} \\
\end{array}$} & \multirow{2}{*}{\multicolumn{2}{|c|}{ Methionine ( $\left.\mu \mathrm{g} \mathrm{g}^{-1} \mathrm{FW}\right)$}} & \multirow{2}{*}{$\begin{array}{l}\text { Total Amino Acids } \\
\quad\left(\mu \mathrm{g} \mathrm{g}^{-1} \mathrm{FW}\right)\end{array}$} \\
\hline $\operatorname{Cr}(\mathrm{VI})(\mu \mathrm{M})$ & MEL (ppm) & & & & & & \\
\hline 0 & 0 & $28.42 \pm 2.48$ & $9.91 \pm 1.03$ & $44.49 \pm 9.005$ & \multicolumn{2}{|c|}{$51.98 \pm 0.79$} & $2504.69 \pm 54.9$ \\
\hline 0 & 125 & $8.56 \pm 2.02$ & $5.82 \pm 0.92$ & $14.39 \pm 2.14$ & \multicolumn{2}{|c|}{$26.21 \pm 0.55$} & $893.15 \pm 24.40$ \\
\hline 0 & 250 & $11.94 \pm 1.48$ & $6.58 \pm 0.44$ & $16.94 \pm 0.90$ & \multicolumn{2}{|c|}{$33.15 \pm 1.47$} & $1223.58 \pm 13.29$ \\
\hline 0 & 500 & $14.78 \pm 0.85$ & $7.38 \pm 0.51$ & $19.38 \pm 0.59$ & \multicolumn{2}{|c|}{$43.61 \pm 0.67$} & $1347.07 \pm 14.95$ \\
\hline 250 & 0 & $4.54 \pm 0.54$ & $3.30 \pm 0.47$ & $9.99 \pm 0.92$ & \multicolumn{2}{|c|}{$9.10 \pm 0.68$} & $591.47 \pm 47.18$ \\
\hline 250 & 125 & $19.49 \pm 0.64$ & $7.47 \pm 0.40$ & $22.49 \pm 1.65$ & \multicolumn{2}{|c|}{$45.85 \pm 1.04$} & $1626.33 \pm 73.72$ \\
\hline 250 & 250 & $23.03 \pm 0.43$ & $8.42 \pm 0.19$ & $26.66 \pm 2.99$ & \multicolumn{2}{|c|}{$47.92 \pm 1.009$} & $1892.25 \pm 29.66$ \\
\hline 250 & 500 & $27.77 \pm 1.03$ & $9.59 \pm 1.17$ & $32.17 \pm 3.34$ & \multicolumn{2}{|c|}{$50.54 \pm 0.52$} & $2208.89 \pm 49.85$ \\
\hline \multicolumn{2}{|c|}{ F-ratio Treatment $(1,16)$} & $24.46^{*}$ & 0.59 & 0.41 & \multicolumn{2}{|c|}{1.08} & $24.5^{*}$ \\
\hline F-ratio & se $(3,16)$ & $28.71^{*}$ & $9.01^{*}$ & $6.87^{*}$ & \multicolumn{2}{|c|}{$366.005^{*}$} & $144.16^{*}$ \\
\hline \multicolumn{2}{|c|}{ F-ratio Treatment $\times$ Dose $_{(3,16)}$} & $250.58^{*}$ & $52.11^{*}$ & $54.57^{*}$ & \multicolumn{2}{|c|}{$1549.31^{*}$} & $1424.96^{*}$ \\
\hline \multicolumn{2}{|c|}{ HSD } & 3.89 & 2.04 & 10.52 & & 2.53 & 122.65 \\
\hline \multirow{2}{*}{\multicolumn{2}{|c|}{ Parameter }} & \multirow{2}{*}{\multicolumn{2}{|c|}{ MLR Equation }} & \multicolumn{3}{|c|}{$\beta$-Regression Coefficient } & Multinle correlation \\
\hline & & & & $\mathrm{Cr}(\mathrm{VI})$ & (MEL) & $(\mathrm{Cr}(\mathrm{VI}) \times \mathrm{MEL})$ & Multiple correlation \\
\hline \multicolumn{2}{|c|}{ Cystine } & \multicolumn{2}{|c|}{$\begin{array}{c}\mathrm{Y}=19.91+-0.04 \mathrm{Cr}(\mathrm{VI})+-0.01(\mathrm{MEL})+0.0002 \\
(\mathrm{Cr}(\mathrm{VI}) \times \mathrm{MEL})\end{array}$} & -0.62 & -0.4 & 1.23 & $0.74^{*}$ \\
\hline \multicolumn{2}{|c|}{ Ornithine } & \multicolumn{2}{|c|}{$\begin{aligned} \mathrm{Y}=8.11+ & -0.01 \mathrm{Cr}(\mathrm{VI})+-0.003(\mathrm{MEL})+6 \\
& \times 10^{-6}(\mathrm{Cr}(\mathrm{VI}) \times \mathrm{MEL})\end{aligned}$} & -0.84 & -0.29 & 1.22 & $0.76^{*}$ \\
\hline \multicolumn{2}{|c|}{ Proline } & \multicolumn{2}{|c|}{$\begin{array}{c}\mathrm{Y}=31.96+-0.07 \mathrm{Cr}(\mathrm{VI})+-0.03(\mathrm{MEL})+0.0003 \\
(\mathrm{Cr}(\mathrm{VI}) \times \mathrm{MEL})\end{array}$} & -0.87 & -0.66 & 1.29 & $0.7^{*}$ \\
\hline \multicolumn{2}{|c|}{ Methionine } & \multicolumn{2}{|c|}{$\begin{array}{c}\mathrm{Y}=39.58+-0.06 \mathrm{Cr}(\mathrm{VI})+-0.004(\mathrm{MEL}) \\
+0.0003(\mathrm{Cr}(\mathrm{VI}) \times \mathrm{MEL})\end{array}$} & -0.58 & -0.05 & 0.89 & 0.65 \\
\hline \multicolumn{2}{|c|}{ Total Amino Acids } & \multicolumn{2}{|c|}{$\begin{array}{c}\mathrm{Y}=1835.4+-3.57 \mathrm{Cr}(\mathrm{VI})+-1.56(\mathrm{MEL})+0.01 \\
(\mathrm{Cr}(\mathrm{VI}) \times \mathrm{MEL})\end{array}$} & -0.73 & -0.47 & 1.25 & $0.71^{*}$ \\
\hline
\end{tabular}

Two-way analysis of the variance of the amino acids revealed that glutamine, $\beta$-alanine and lysine, asparagine, serine, isoleucine, threonine, arginine, cystine, and the total amino acids were statistically significant for the $\mathrm{Cr}(\mathrm{VI})$, MEL, and $\mathrm{Cr}(\mathrm{VI}) \times$ MEL treatments, whereas the $\mathrm{F}$ ratios of aspartic acid, glutamic acid, glycine, citrulline, GABA, ornithine, proline, and methionine were statistically significant for MEL and $\mathrm{Cr}(\mathrm{VI}) \times$ MEL but not for the $\mathrm{Cr}(\mathrm{VI})$ treatment. MLR analysis of aspartic acid resulted in positive values of the $\beta$-regression coefficient for $\mathrm{Cr}(\mathrm{VI})$ treatment and positive values of the $\beta$-regression coefficients for the combined $\mathrm{Cr}(\mathrm{VI}) \times$ MEL treatment, which reveals that $\mathrm{Cr}(\mathrm{VI})$ stress decreased, whereas, $\mathrm{Cr}(\mathrm{VI}) \times \mathrm{MEL}$ increased the aspartic acid content in the Vigna radiata plants. The glutamine, $\beta$-alanine, lysine (Table 8 ), glutamic acid, asparagine, serine, isoleucine (Table 9), glycine, threonine, citrulline, arginine, GABA (Table 10), cystine, ornithine, proline, methionine, and total amino acids (Table 11) revealed negative values of the $\beta$-regression coefficients for $\mathrm{Cr}(\mathrm{VI})$ treatment, indicating its negative effect, and positive values of the $\beta$-regression coefficients for the interaction of $\mathrm{Cr}(\mathrm{VI}) \times \mathrm{MEL}$, indicating the increasing effect in the amino acids.

\subsection{Organic Acids}

Data obtained on the effect of $\mathrm{Cr}(\mathrm{VI})$ exposure and the combination of MEL with $\mathrm{Cr}(\mathrm{VI})$ treatment on the organic acids of the Krebs cycle (citrate, succinate, fumarate, and malate) in Vigna radiata plants are presented in Table 12. The fumaric acid content was elevated to $0.415 \mathrm{mg} \mathrm{g}^{-1} \mathrm{DW}$ (dry weight) in $\mathrm{Cr}(\mathrm{VI})$-treated plants in comparison to control plants $\left(0.38 \mathrm{mg} \mathrm{g}^{-1} \mathrm{DW}\right)$. The $500 \mathrm{ppm}$ MEL application to the $\mathrm{Cr}(\mathrm{VI})$-treated plants enhanced the fumaric acid content to $0.416 \mathrm{mg} \mathrm{g}^{-1} \mathrm{DW}$. The citric acid content also increased to $2.94 \mathrm{mg} \mathrm{g}^{-1} \mathrm{DW}$ in $\mathrm{Cr}(\mathrm{VI})$-exposed plants as compared to $2.32 \mathrm{mg} \mathrm{g}^{-1} \mathrm{DW}$ in unexposed plants. Treatment with $500 \mathrm{ppm}$ MEL further enhanced its content to $3.68 \mathrm{mg} \mathrm{g}^{-1}$ $\mathrm{DW}$ in $\mathrm{Cr}(\mathrm{VI})$-treated plants as compared to non-treated plants. An enhancement was observed in the malic acid content of $\mathrm{Cr}(\mathrm{VI})$-treated plants to $2.15 \mathrm{mg} \mathrm{g}^{-1} \mathrm{DW}$ in comparison with control plants, which contained $1.47 \mathrm{mg}$ malic acid content $\mathrm{g}^{-1} \mathrm{DW}$. Co-application of different MEL concentrations $(125,250$, and $500 \mathrm{ppm})$ to $\mathrm{Cr}(\mathrm{VI})$-stressed plants resulted in an increase of the malic acid content to 2.19, 
2.48 , and $2.50 \mathrm{mg} \mathrm{g}^{-1} \mathrm{DW}$, respectively. The succinic acid content followed the same trend. The succinic acid content in control plants was observed to be $0.870 \mathrm{mg} \mathrm{g}^{-1} \mathrm{DW}$, which increased to $0.876 \mathrm{mg} \mathrm{g}^{-1}$ DW with Cr(VI) application. Supplementation with 125, 250, and 500 ppm MEL to Cr(VI)-exposed plants increased the succinic acid content to $0.867,0.884$, and $0.899 \mathrm{mg} \mathrm{g}^{-1} \mathrm{DW}$, respectively.

Two-way ANOVA revealed that the $\mathrm{F}$ ratios of all the four organic acids were statistically significant under $\mathrm{Cr}(\mathrm{VI})$ treatment, whereas the $\mathrm{F}$ ratio of the MEL dose was only significant in case of the citric acid content. F ratios for the interaction of $\mathrm{Cr}(\mathrm{VI}) \times$ MEL were statistically significant for the fumaric acid, citric acid, and succinic acid but not significant for the malic acid content. HSD values for fumaric acid, malic acid, citric acid, and succinic acid contents were noted to be $0.02,0.61,0.4$, and 0.09 , respectively. MLR analysis revealed the positive impact of $\mathrm{Cr}(\mathrm{VI})$ treatment (positive $\beta$ values) and the negative impact of the interaction of $\mathrm{Cr}(\mathrm{VI}) \times \mathrm{MEL}$ (positive $\beta$ values) on thefumaric acid and succinate contents, whereas $\mathrm{Cr}(\mathrm{VI})$ and $\mathrm{Cr}(\mathrm{VI}) \times$ MEL had a positive effect (positive $\beta$ values) on the malic acid and citric acid contents.

Table 12. Effect of $\mathrm{Cr}(\mathrm{VI})$, different concentrations of methanol extract of Rhododendron arboreum leaves (MEL), and their combinations on fumaric acid, malic acid, citric acid, and succinic acid content in 7-day-old Vigna radiata seedlings. The values are the means of three replicates \pm SD. (standard deviation). Tukeys test performed and significance checked at ${ }^{*} p \leq 0.05$. The $\mathrm{F}$ ratio is the term in which ANOVA is represented; $\mathrm{Cr}(\mathrm{VI})=$ Dose, MEL treatments = Treatment and combination of $\mathrm{Cr}(\mathrm{VI})$ and MEL $=$ Dose $\times$ treatment.

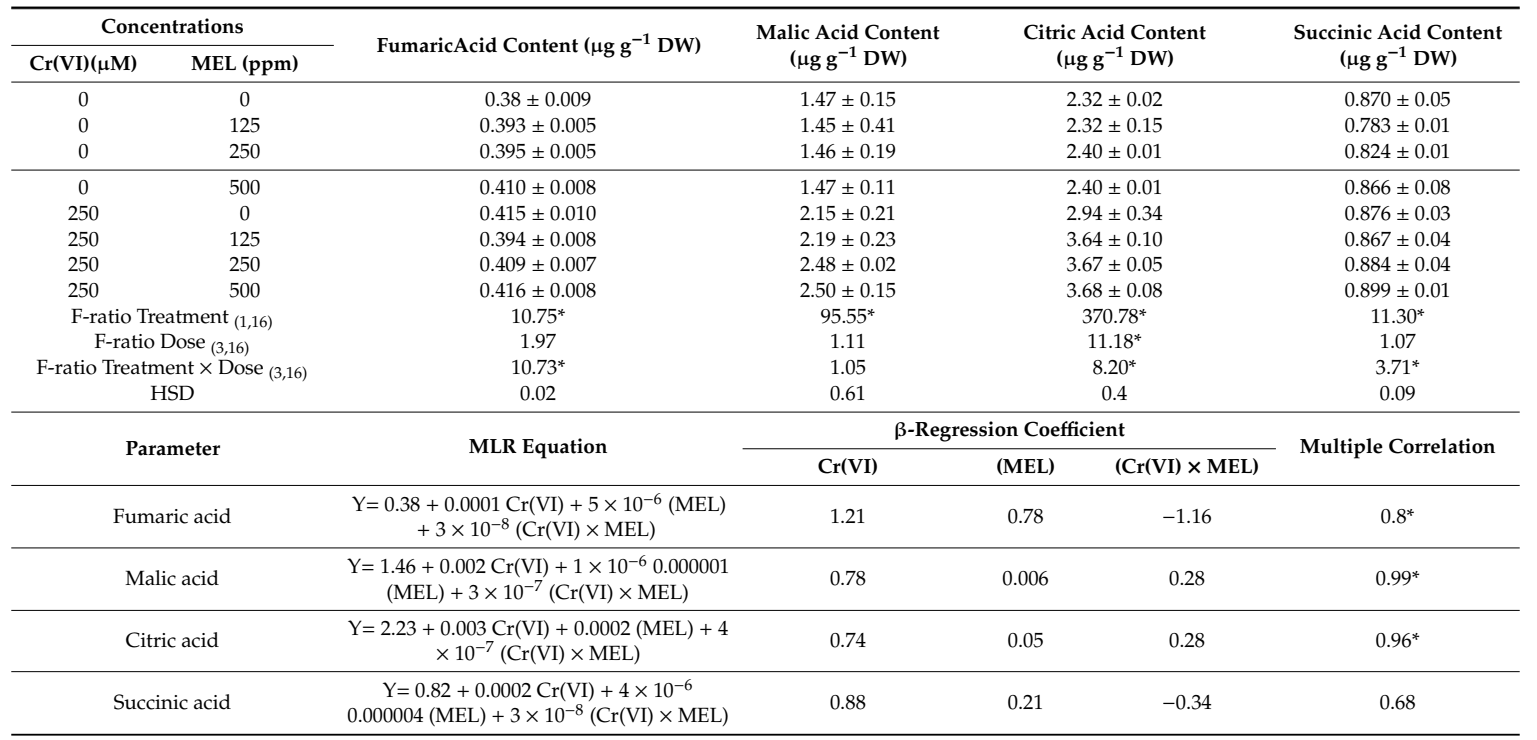

\section{Discussion}

Heavy metal contamination in soil is one of the foremost problems accountable for a reduction in agricultural yield. The most crucial segments of plant life are seed germination and growth of seedlings and these are adversely affected by metal stress [36]. Plants exposed to metal stress endure plentiful physiological and biochemical alterations because metal exposure involves oxidative stress [36]. The embarkment of stress endurance takes place when a stress causative agent approaches the cell surface or penetrates into the cytoplasm and injures the cell. The successive events intended to reinstate cell function are regarded as the stress response. The stress response is activated by a signal from a suitable receptor instantaneously after the commencement of the prevalence of the stress factor. At this stage, cell organization and utility is hindered. Oxidative damage generated by stress in the plant tissue is controlled by a combined operation of both antioxidant enzymes as well as non-enzymatic antioxidant systems. Apart from those, pigments, polyphenols, organic acids, and amino acids also play a key role in the plant defense against abiotic stress. 
In the present study, the effect of Cr stress and MEL application on anthocyanin and xanthophyll pigments was observed. The results revealed that $\mathrm{Cr}$ treatment significantly enhanced the anthocyanin and xanthophyll content in comparison to untreated plants. Our results coincide with the findings of Kohli et al. [37], who observed an enhancement of anthocyanins and xanthophylls along with $\mathrm{Pb}$ metal stress in mustard, as well as Posmyk et al. [38], who reported an improvement in the anthocyanin content in red cabbage seedlings under $\mathrm{Cu}$ stress. The supplementation of MEL at 125, 250, and $500 \mathrm{ppm}$ concentrations along with $\mathrm{Cr}(\mathrm{VI})$ metal stress further enhanced the pigment contents. Anthocyanins are involved in plants responses to various abiotic stresses and are reported to enhance stress tolerance by scavenging ROS or playing a role in stress signals. Kovinich et al. [39] reported that in response to various abiotic stresses in Arabidopsis, anthocyanins had diverse localizations at the tissue and organ levels. Anthocyanins amend the ROS level and the sensitivity to ROS-generating stresses in sustaining photosynthetic capacity [40]. Xanthophylls are considered as key antioxidants that defend plants subjected to heavy metal stress [41]. Xanthophyll is also vital for photo-protection; hence, its accumulation may downregulate Photosystem II actions to diminish oxidative damage [42]. Though reports explaining the approach to recover the pigment contents under stress are exclusively meager, the existing studies demonstrate that exogenous application of growth regulators improve the drought tolerance with increased activities of SOD, CAT, APX, ABA, and total improved pigment contents in maize [43]. The protein content in 7-day-old Vigna radiata $\mathrm{Cr}(\mathrm{VI})$-stressed plants was observed to decrease as compared to the untreated control plants, whereas all the enzymes (SOD, POD, CAT, APOX, GR, DHAR, PPO, GST, and GPOX) in 7-day-old Vigna radiata plants showed enhanced activities under $\mathrm{Cr}(\mathrm{VI})$ stress. These results are in accordance with Rai et al. [44], who reported a decrease in protein and increase in enzymes with Cr stress. MEL supplementation showed an improvement in the protein content in $\mathrm{Cr}(\mathrm{VI})$-treated plants. The combination of $\mathrm{Cr}(\mathrm{VI})$ and MEL further increased enzymatic activity at all concentrations when compared to $\mathrm{Cr}(\mathrm{VI})$ alone. SOD catalyzes the dismutation of the superoxide anion to di-oxygen and $\mathrm{H}_{2} \mathrm{O}_{2}$. Non-specific peroxidases are responsible for scavenging $\mathrm{H}_{2} \mathrm{O}_{2}$. Several reductases, like DHAR and GR, are responsible for keeping ascorbate and glutathione in the reduced form. SOD and catalase hold metal ions on their active sites as a fundamental fraction to combat the toxic effects of metal-stimulated ROS. The increase in both the protein content as well as enzymatic antioxidants supports the protective role of MEL towards the Vigna radiata plants to overcome the oxidative stress caused by $\mathrm{Cr}(\mathrm{VI})$. The non-enzymatic antioxidants, ascorbic acid, tocopherol, and glutathione, increased with $\mathrm{Cr}(\mathrm{VI})$ in comparison to untreated plants. The combination of $\mathrm{Cr}(\mathrm{VI})$ and MEL further enhanced the ascorbic acid, tocopherol, and glutathione contents and the maximum respective increase was observed in the case of $\mathrm{Cr}(\mathrm{VI}) \times 500 \mathrm{ppm}$ MEL. Ascorbic acid is a well-known antioxidant involved in various processes, for example, cell wall expansion and cell division [45]. It scavenges free radicals directly in the aqueous phases of cells and guards the membrane and other hydrophobic sections from oxidative injury by redeveloping the antioxidant form of vitamin E [46]. It is also renowned for promoting photosynthetic pigments and improving the tolerance of plants in opposition to diverse stresses by scavenging ROS $[47,48]$. Therefore, the enhancement of anthocyanin and xanthophyll pigments in the present study might be attributed to the increased ascorbic acid content due to MEL application. Tocopherol is a water-soluble antioxidant found in chloroplasts that enhances pigment synthesis and modifies the biosynthesis pathways of pigments under stress conditions. Under salinity stress, it has been reported to play a role in several physiological functions, including growth regulation and the differentiation of plants [49,50]. Further, tocopherol has also been reported to protect cells from hydrogen peroxide and other free radicals generated in salinity stress by direct scavenging of ROS as well as collaborative action with antioxidant enzymes and other antioxidants [51-53]. An increase in the tocopherol content in Arabidopsis thaliana in response to $\mathrm{Cd}$ and $\mathrm{Cu}$ stress was observed [54]. The reason for this enhancement was the increase in transcripts encoding enzymes of the tocopherol biosynthetic pathway in response to metal exposure. The vitamin E-deficient (vte1) mutant was observed to be more prone to metal-induced stress compared to the wild-type (WT) control. 
It was concluded that tocopherol plays a vital function in the tolerance of Arabidopsis to oxidative stress induced by heavy metals, such as $\mathrm{Cu}$ and $\mathrm{Cd}$ [54]. Glutathione plays a central role in the scavenging of ROS as well as in the chelation of heavy metals. GSH protects the plants from heavy metal-induced oxidative damage by chelation, detoxification, and compartmentalization of heavy metals. Additionally, it acts through its metabolizing enzymes, particularly glutathione peroxidase, glutathione-S-transferase, glutathione reductase, and dehydroascorbate reductase, for efficient protection against ROS [55].

Polyphenols are proven stress busters for their ROS scavenging potential. Five polyphenols, namely gallic acid, chlorogenic acid, caffeic acid, catechin, and coumaric acid, were found to be present in the plants and a considerable increase in the levels of all polyphenolic compounds with Cr was observed in the present study. Kohli et al. [37] also established the increase in polyphenol contents under metal stress. This could be due to the increased activity of a variety of enzymes, such as chalcone synthase and cinnamate 4-hydroxylase, which are responsible for polyphenol synthesis [56,57]. In the present study, the combination of $\mathrm{Cr}(\mathrm{VI})$ and MEL further enhanced the polyphenol contents. It has been previously reported that antioxidants produced within plants reduce the effects of stresses in plants $[58,59]$. Those polyphenols possess the affinity to bind with metal ions and thereby inhibit the production of several ROS and some of them sequester the heavy metals entering the cell [60].

Amino acids are the building blocks of proteins. Different amino acids, namely aspartic acid, glutamine, $\beta$-alanine, lysine, glutamic acid, asparagine, serine, isoleucine, glycine, threonine, citrulline, arginine, GABA, cystine, ornithine, proline, and methionine, decreased with $\mathrm{Cr}(\mathrm{VI})$ stress when compared to control plants. This trend correlates with the decreased amount of protein in the present study. MEL recovered the amino acid content in the $\mathrm{Cr}(\mathrm{VI})$-stressed plants. As compared to control plants, the contents of four organic acids (fumarate, citrate, malate, and succinate) were increased with $\mathrm{Cr}(\mathrm{VI})$ stress. The present study is in agreement with the work of Kohli et al. [61] and Ma [62], who reported that organic acids increase in abiotic stress conditions. Co-application of MEL along with $\mathrm{Cr}(\mathrm{VI})$ further increased the organic acid contents as compared to only $\mathrm{Cr}(\mathrm{VI})$-treated plants, indicating the stress protective role of organic acids. Amino acids and organic acids are metabolites that have been reported to impart tolerance against heavy metal stress [63-65]. The utility of some of them is still unknown due to the convolution in plant responses to these stresses. In case of heavy metal stress, two mechanisms of detoxification and tolerance take place. Detoxification is external whereas tolerance is an internal process. In detoxification, plant roots secrete organic acids, which bind with metal ions to alter their movement as well as bioavailability, leading to the prevention of heavy metal uptake by plants. Meanwhile, in internal heavy metal tolerance, organic acids might chelate the metal ions inside the cytosol, converting them to less toxic or totally nontoxic byproducts $[66,67]$. Different plants have been reported to create a variety of ligands for aluminum, cadmium, copper, nickel, cobalt, and zinc. Amino acids and organic acids, such as citrate and malate, are reported to be probable ligands for heavy metals and are established to be engaged in their tolerance and detoxification [66-69]. Oven et al. [70] observed that cobalt metal treatment to a Co-hyperaccumulator, namely Crotalaria cobalticola, and non-accumulators, Raufolia serpentina and Silene cucubalus, resulted in an enhancement of citrate, indicating its participation in the heavy metal ion complex formation. Malate is reported to chelate zinc in the cytosols of $\mathrm{Zn}$ hyperaccumulators [71]. Zhang et al. [72] observed that taking away the aluminum from the roots leads to a quick decrease in malate release to the non-aluminum point, which demonstrated a receptive aluminum and malate-secreting mechanism. Over $24 \mathrm{~h}$ of exposure to $50 \mu \mathrm{M}$ aluminum, 10 -fold elevated malate and three- to five-fold elevated succinate secretion was observed in aluminum-tolerant genotypes as compared to aluminum-sensitive seedlings [73].

Ellagic acid has been reported by Ascacio-Valdés et al. [74] to have the ability to protect plants against stresses because of its antioxidant activity. Moreover, Khan et al. [75] reported that ellagic acid is one of the best antioxidants to shield Brassica napus L. plants against salinity stress, and due to its antioxidant properties, ellagic acid can enhance the growth and yield of the crop. Rhododendron leaf extract (MEL) is enriched with ellagic acid and several other antioxidant polyphenolic compounds. 
As a natural source of ellagic acid, it is as beneficial as pure ellagic acid for improving stress tolerance by regulating different physiological processes under $\mathrm{Cr}$ metal stress. Consequently, Rhododendron leaf extract can be used as an economical source of polyphenols, especially ellagic acid, for safeguarding plants from toxic effects of $\mathrm{Cr}$ stress.

\section{Conclusions}

In the present study, Cr stress brought about physiological as well as metabolic alterations in Vigna radiata plants even at small concentrations. The Rhododendron leaf extract supplementation to Cr-stressed Vigna radiata plants helps in tolerating $\mathrm{Cr}$ toxicity by modulating the contents of pigments and activation of the enzymatic as well as non-enzymatic antioxidativedefense system. It also restored polyphenols, organic acids, and amino acids, which also provides extra protection to the plants from $\mathrm{Cr}$ stress. We thus conclude that exogenous application of Rhododendron leaf extract (rich in ellagic acid) reduced the effect of chromium metal stress in Vigna radiata plants. Further prospects of the work will be intended towards fortification of the idea of the stress ameliorative activity of Rhododendron extract by investigating the mechanism attributed to the increased defense of plants against heavy metal stress.

Author Contributions: Conceptualization, V.G., R.B. and P.A.; methodology, V.G. and P.S.; software, B.A.P. and M.N.A.; validation, P.B., S.A. and P.A.; formal analysis, R.B. and M.N.A.; investigation, V.G. and P.S.; resources, R.B. and P.A.; data curation, P.B. and B.A.P.; writing-Original draft preparation, V.G.; P.S., P.B. and S.A.; writing-Review and editing, R.B., P.A. and M.N.A.; visualization, V.G.; P.A. and R.B.; supervision, R.B.; project administration, R.B.; funding acquisition, B.A.P.; M.N.A. and P.A. All authors have read and agreed to the published version of the manuscript.

Funding: RSP-2019/116.

Acknowledgments: The authors would like to extend their sincere appreciation to the Researchers Supporting Project Number (RSP-2019/116), King Saud University, Riyadh, Saudi Arabia.

Conflicts of Interest: The authors declare no conflict of interest.

\section{References}

1. Hasanuzzaman, M.; Fujita, M. Heavy metals in the environment: Current status, toxic effects on plants and possible phytoremediation. In Phytotechnologies: Remediation of Environmental Contaminants; Anjum, N.A., Pereira, M.A., Ahmad, I., Duarte, A.C., Umar, S., Khan, N.A., Eds.; Taylor and Francis/CRC Press: Boca Raton, FL, USA, 2012; pp. 7-73.

2. Jomovaa, K.; Valkob, M. Advances in metal-induced oxidative stress and human disease. Toxicology 2011, 283, 65-87. [CrossRef] [PubMed]

3. Dheeba, B.; Sampathkumar, P. Ameliorating effect of fertilizers on biochemical characteristics of Vigna radiata treated with hexavalent chromium. Biosci. Biotechnol. Res. Asia 2014, 11, 301-307. [CrossRef]

4. Oliveira, H. Chromium as an environmental pollutant: Insights on induced plant toxicity. J. Bot. 2012. [CrossRef]

5. Panda, S.K. Chromium-mediated oxidative stress and ultrastructural changes in root cells of developing rice seedlings. J. Plant Physiol. 2007, 164, 1419-1428. [CrossRef]

6. Ahmad, P.; Jaleel, C.A.; Salem, M.A.; Nabi, G.; Sharma, S. Roles of enzymatic and nonenzymatic antioxidants in plants during abiotic stress. Crit. Rev. Biotechnol. 2010, 30, 161-175. [CrossRef]

7. Ighodaro, O.M.; Akinloye, O.A. First line defence antioxidants-superoxide dismutase (SOD), catalase (CAT) and glutathione peroxidase (GPX): Their fundamental role in the entire antioxidant defence grid. Alex. J. Med. 2018, 54, 287-293. [CrossRef]

8. Niwa, T.; Doi, U.; Kato, Y.; Osawa, T. Antioxidative Properties of Phenolic Antioxidants Isolated from Corn Steep Liquor. J. Agric. Food Chem. 2001, 49, 177-182. [CrossRef]

9. Singh, R.; Kaushik, S.; Wang, Y.; Xiang, Y.; Novak, I.; Komatsu, M.; Tanaka, K.; Cuervo, A.M.; Czaja, M.J. Autophagy regulates lipid metabolism. Nature 2009, 458, 1131-1135. [CrossRef]

10. Andresen, M.; Cedergreen, N. Plant growth is stimulated by tea-seed extract: A new natural growth regulator? Hortscience 2010, 45, 1848-1853. [CrossRef] 
11. Gautam, V.; Kohli, S.; Arora, S.; Bhardwaj, R.; Kazi, M.; Ahmad, A.; Raish, M.; Ganaie, M.; Ahmad, P. Antioxidant and Antimutagenic Activities of Different Fractions from the Leaves of Rhododendron arboreum Sm. and Their GC-MS Profiling. Molecules 2018, 23, 2239. [CrossRef]

12. Painuli, S.; Rai, N.; Kumar, N. Gas chromatography and mass spectrometry analysis of methanolic extract of leaves of Rhododendron arboreum. Asian J. Pharm. Clin. Res. 2016, 9, 66-69.

13. Roy, J.D.; Handique, A.K.; Barua, C.C.; Talukdar, A.; Ahmed, F.A.; Barua, I.C. Evaluation of phytoconstituents and assessment of adaptogenic activity in vivo in various extracts of Rhododendron arboreum (leaves). J. Pharm. Biol. Res. 2014, 2, 49-56. [CrossRef]

14. Kiruba, S.; Mahesh, M.; Nisha, S.R.; Paul, Z.M.; Jeeva, S. Phytochemical analysis of the flower extracts of Rhododendron arboreum Sm. ssp. nilagiricum (Zenker) Tagg. Asian Pac. J. Trop. Biomed. 2011, 1, S284-S286. [CrossRef]

15. Rath, B.P.; Hota, S.; Subhadarshini, S.; Dash, D.; Das, P.K. Consequence of chromium-tainted soil on physical and biochemical responses of Vigna radiata L. J. Appl. Biol. Biotechnol. 2019, 7, 35-41.

16. Cobbett, C.S. Heavy metals and plants-model systems and hyper accumulators. New Phytol. 2003, 159, $289-293$. [CrossRef]

17. Lawrence, J. Determination of total xanthophyll and marigold oleoresin. J. Ass. Off. Anal. Chem. 1990, 2, 970-975.

18. Mancinelli, A.L. Photoregulation of Anthocyanin Synthesis. Plant Physiol. 1984, 75, 447-453. [CrossRef]

19. Lowry, O.H.; Rosebrough, N.J.; Farr, A.L.; Randall, R.J. Protein measurement with the Folin phenol reagent. J. Biol. Chem. 1951, 193, 265-275.

20. Pütter, J. Peroxidases. In Methods of Enzymatic Analysis; Elsevier: Amsterdam, The Netherlands, 1974; pp. 685-690. [CrossRef]

21. Aebi, H. Catalase in vitro. In Methods in Enzymology; Elsevier: Amsterdam, The Netherlands, 1984; pp. 121-126. [CrossRef]

22. Kono, Y. Generation of superoxide radical during autoxidation of hydroxylamine and an assay for superoxide dismutase. Arch. Biochem. Biophys. 1978, 186, 189-195. [CrossRef]

23. Nakano, Y.; Asada, K. Hydrogen-Peroxide Is Scavenged by Ascorbate-Specific Peroxidase in Spinach-Chloroplasts. Plant Cell Physiol. 1981, 22, 867-880. [CrossRef]

24. Carlberg, I.; Mannervik, B. Purification and characterization of the flavoenzyme glutathione reductase from rat liver. J. Biol. Chem. 1975, 250, 5475-5480. [PubMed]

25. Dalton, D.A.; Russell, S.A.; Hanus, F.J.; Pascoe, G.A.; Evans, H.J. Enzymatic reactions of ascorbate and glutathione that prevent peroxide damage in soybean root nodules. Proc. Natl. Acad. Sci. USA 1986, 83, 3811-3815. [CrossRef] [PubMed]

26. Kumar, K.; Khan, P. Age-related changes in catalase and peroxidase activities in the excised leaves of Eleusine coracana Gaertn. cv PR 202 during senescence. Exp. Gerontol. 1982, 18, 409-417. [CrossRef]

27. Habig, W.H.; Jakoby, W.B. Assays for differentiation of glutathione S-Transferases. In Methods in Enzymology; Elsevier: Amsterdam, The Netherlands, 1981; pp. 398-405. [CrossRef]

28. Flohé, L.; Günzler, W.A. Assays of glutathione peroxidase. In Methods in enzymology; Elsevier: Amsterdam, The Netherlands, 1984; Volume 105, pp. 114-120.

29. Roe, J.H.; Kuether, C.A. The determination of ascorbic acid in whole blood and urine through the 2, 4-dinitrophenylhydrazine derivavative of dehydroascorbic acid. J. Biol. Chem. 1943, 147, 399-407.

30. Martinek, R.G. Method for the determination of vitamin E (total tocopherols) in serum. Clin. Chem. 1964, 10, 1078-1086. [CrossRef] [PubMed]

31. Sedlak, J.; Lindsay, R.H. Estimation of total, protein-bound, and nonprotein sulfhydryl groups in tissue with Ellman's reagent. Anal. Biochem. 1968, 25, 192-205. [CrossRef]

32. Hartmann, T.N.; Fricker, M.D.; Rennenberg, H.; Meyer, A.J. Cell-specific measurement of cytosolic glutathione in poplar leaves. Plant Cell Environ. 2003, 26, 965-975. [CrossRef]

33. Iriti, M.; Rossoni, M.; Borgo, M.; Ferrara, L.; Faoro, F. Induction of Resistance to Gray Mold with Benzothiadiazole Modifies Amino Acid Profile and Increases Proanthocyanidins in Grape: Primary versus Secondary Metabolism. J. Agric. Food Chem. 2005, 53, 9133-9139. [CrossRef]

34. Chen, M.-C.; Wang, M.-K.; Chiu, C.-Y.; Huang, P.-M.; King, H.-B. Determination of low molecular weight dicarboxylic acids and organic functional groups in rhizosphere and bulk soils of Tsuga and Yushania in a temperate rain forest. Plant Soil 2001, 231, 37-44. [CrossRef] 
35. Bailey, N.T. Statistical Methods in Biology; Cambridge University Press: Cambridge, UK, 1995.

36. El-Soud, W.A.; Hegab, M.M.; AbdElgawad, H.; Zinta, G.; Asard, H. Ability of ellagic acid to alleviate osmotic stress on chickpea seedlings. Plant Physiol. Biochem. 2013, 71, 173-183. [CrossRef]

37. Kohli, S.K.; Handa, N.; Sharma, A.; Gautam, V.; Arora, S.; Bhardwaj, R.; Wijaya, L.; Alyemeni, M.N.; Ahmad, P. Interaction of 24-epibrassinolide and salicylic acid regulates pigment contents, antioxidative defense responses, and gene expression in Brassica juncea L. seedlings under Pb stress. Environ. Sci. Pollut. Res. 2018, 25, 15159-15173. [CrossRef] [PubMed]

38. Posmyk, M.M.; Kontek, R.; Janas, K.M. Antioxidant enzymes activity and phenolic compounds content in red cabbage seedlings exposed to copper stress. Ecotoxicol. Environ. Saf. 2009, 72, 596-602. [CrossRef] [PubMed]

39. Kovinich, N.; Kayanja, G.; Chanoca, A.; Otegui, M.S.; Grotewold, E. Abiotic stresses induce different localizations of anthocyanins in Arabidopsis. Plant Signal Behav. 2015, 10, e1027850. [CrossRef] [PubMed]

40. Xu, Z.; Mahmood, K.; Rothstein, S.J. ROS Induces Anthocyanin Production Via Late Biosynthetic Genes and Anthocyanin Deficiency Confers the Hypersensitivity to ROS-Generating Stresses in Arabidopsis. Plant Cell Physiol. 2017, 58, 1364-1377. [CrossRef]

41. Baek, S.-A.; Han, T.; Ahn, S.-K.; Kang, H.; Cho, M.R.; Lee, S.-C.; Im, K.-H. Effects of Heavy Metals on Plant Growths and Pigment Contents in Arabidopsis thaliana. Plant Pathol. J. 2012, 28, 446-452. [CrossRef]

42. Ji, Y.; Xie, X.; Wang, G. Effects of the heavy metal cadmium on photosynthetic activity and the xanthophyll cycle in Phaeodactylum tricornutum. J. Oceanol. Limnol. 2018, 36, 2194-2201. [CrossRef]

43. Ahmad, S.; Kamran, M.; Ding, R.; Meng, X.; Wang, H.; Ahmad, I.; Fahad, S.; Han, Q. Exogenous melatonin confers drought stress by promoting plant growth, photosynthetic capacity and antioxidant defense system of maize seedlings. Peer] 2019, 7, e7793. [CrossRef]

44. Rai, V.; Vajpayee, P.; Singh, S.N.; Mehrotra, S. Effect of chromium accumulation on photosynthetic pigments, oxidative stress defense system, nitrate reduction, proline level and eugenol content of Ocimum tenuiflorum $\mathrm{L}$. Plant Sci. 2004, 167, 1159-1169. [CrossRef]

45. Hameed, A.; Gulzar, S.; Aziz, I.; Hussain, T.; Gul, B.; Khan, M.A. Effects of salinity and ascorbic acid on growth, water status and antioxidant system in a perennial halophyte. AoB PLANTS 2015, 7. [CrossRef]

46. Hasanuzzaman, M.; Bhuyan, M.H.M.B.; Anee, T.I.; Parvin, K.; Nahar, K.; Mahmud, J.A.; Fujita, M. Regulation of ascorbate-glutathione pathway in mitigating oxidative damage in plants under abiotic stress. Antioxidants 2019, 8, 384. [CrossRef]

47. Dey, S.; Sidor, A.; O’Rourke, B. Compartment-specific Control of Reactive Oxygen Species Scavenging by Antioxidant Pathway Enzymes. J. Biol. Chem. 2016, 291, 11185-11197. [CrossRef] [PubMed]

48. Collin, V.C.; Eymery, F.; Genty, B.; Rey, P.; Havaux, M. Vitamin E is essential for the tolerance of Arabidopsis thaliana to metal-induced oxidative stress. Plant Cell Environ. 2008, 31, 244-257. [CrossRef] [PubMed]

49. Hossain, M.A.; Piyatida, P.; Teixeira-da-Silva, J.A.; Fujita, M. Molecular mechanism of heavy metal toxicity and tolerance in plants: Central role of glutathione in detoxification of reactive oxygen species and methylglyoxal and in heavy metal chelation. J. Bot. 2012, 2012, 872875. [CrossRef]

50. Gallie, D.R. L-Ascorbic Acid: A Multifunctional Molecule Supporting Plant Growth and Development. Scientifica 2013, 2013, 795964. [CrossRef] [PubMed]

51. Azooz, M.M.; Hassanein, A.M.; Faheed, F.A. Riboflavin (vitamin B2) treatments counteract the adverse effects of salinity on growth and some relevant physiological responses of Hibiscus sabdariffa L. seedlings. Bull. Fac. Sci. Assuit Univ. 2002, 31, 395-403.

52. Barakat, H. Interactive effects of salinity and certain vitamin on gene expression and cell division. Int. J. Agric. Biol. 2003, 3, 219-225.

53. Cvelkorska, M.; Rampitsch, C.; Bykova, N.; Xing, T. Genomic analysis of MAP kinase cascades in Arabidopsis defense responses Plant Mol. Biol. Report. 2005, 23, 331-343.

54. Pourcel, L.; Routaboul, J.M.; Cheynier, V. Flavonoid oxidation in plants: From biochemical properties to physiological functions. Trends Plant Sci. 2007, 12, 29-36. [CrossRef]

55. Hasanuzzaman, M.; Nahar, K.; Rahman, A.; Mahmud, J.A.; Alharby, H.F.; Fujita, M. Exogenous glutathione attenuates lead-induced oxidative stress in wheat by improving antioxidant defense and physiological mechanisms. J. Plant Interact. 2018, 13, 203-212. [CrossRef]

56. Dai, J.; Mumper, R.J. Plant Phenolics: Extraction, Analysis and Their Antioxidant and Anticancer Properties. Molecules 2010, 15, 7313-7352. [CrossRef] 
57. Xi, Z.-m.; Zhang, Z.-w.; Huo, S.-s.; Luan, L.-y.; Gao, X.; Ma, L.-n.; Fang, Y.-1. Regulating the secondary metabolism in grape berry using exogenous 24-epibrassinolide for enhanced phenolics content and antioxidant capacity. Food Chem. 2013, 141, 3056-3065. [CrossRef] [PubMed]

58. Agada, O.O. Abiotic Stress, Antioxidants and Crop Productivity: The Mitigating Role of Exogenous Substances. Greener J. Agric. Sci. 2016, 6, 79-86. [CrossRef]

59. Alhasnawi, A.N.; Kadhimi, A.A.; Isahak, A.; Mohamad, A.; Yusoff, W.M.W.; Zain, C.R.C.M. Exogenous Application of Ascorbic Acid Ameliorates Detrimental Effects of Salt Stress in Rice (MRQ74 and MR269) Seedlings. Asian J. Crop Sci. 2015, 7, 186-196. [CrossRef]

60. Jung, C.; Maeder, V.; Funk, F.; Frey, B.; Sticher, H.; Frossard, E. Release of phenols from Lupinus albus L. roots exposed to $\mathrm{Cu}$ and their possible role in Cu detoxification. Plant Soil 2003, 252, 301-312. [CrossRef]

61. Kohli, S.K.; Handa, N.; Sharma, A.; Gautam, V.; Arora, S.; Bhardwaj, R.; Alyemeni, M.N.; Wijaya, L.; Ahmad, P. Combined effect of 24-epibrassinolide and salicylic acid mitigates lead $(\mathrm{Pb})$ toxicity by modulating various metabolites in Brassica juncea L. seedlings. Protoplasma 2018, 255, 11-24. [CrossRef]

62. Ma, J.F. Role of Organic Acids in Detoxification of Aluminum in Higher Plants. Plant Cell Physiol. 2000, 41, 383-390. [CrossRef]

63. Callahan, D.L.; Baker, A.J.M.; Kolev, S.D.; Wedd, A.G. Metal ion ligands in hyperaccumulating plants. J. Biol. Inorg. Chem. 2006, 11, 2-12. [CrossRef]

64. Yusuf, M.; Fariduddin, Q.; Ahmad, A. 24-Epibrassinolide modulates growth, nodulation, antioxidant system, and osmolyte in tolerant and sensitive varieties of Vigna radiata under different levels of nickel: A shotgun approach. Plant Physiol. Biochem. 2012, 57, 143-153. [CrossRef]

65. Singh, S.; Parihar, P.; Singh, R.; Singh, V.P.; Prasad, S.M. Heavy metal tolerance in plants: Role of transcriptomics, proteomics, metabolomics, and ionomics. Front. Plant Sci. 2015, 6, 1143. [CrossRef]

66. Hall, J.L. Cellular mechanisms for heavy metal detoxification and tolerance. J. Exp. Bot. 2002, 53, 1-11. [CrossRef]

67. Yang, X.E.; Jin, X.F.; Feng, Y.; Islam, E. Molecular mechanisms and genetic basis of heavy metal tolerance/hyperaccumulation in plants. J. Integr. Plant Biol. 2005, 47, 1025-1035. [CrossRef]

68. Sharma, S.S.; Dietz, K.J. The relationship between metal toxicity and cellular redox imbalance. Trends Plant Sci. 2009, 14, 43-50. [CrossRef] [PubMed]

69. Clemens, S. Molecular mechanisms of plant metal tolerance and homeostasis. Planta 2001, 212, 475-486. [CrossRef] [PubMed]

70. Oven, M.; Grill, E.; Golan-Goldhirsh, A.; Kutchan, T.M.; Zenk, M.H. Increase of free cysteine and citric acid in plant cells exposed to cobalt ions. Phytochemistry 2002, 60, 467-474. [CrossRef]

71. Sinclair, S.A.; Krämer, U. The zinc homeostasis network of land plants. Biochim. Et Biophys. Acta Mol. Cell Res. 2012, 1823, 1553-1567. [CrossRef]

72. Zhang, W.H.; Ryan, P.R.; Tyerman, S.D. Malate permeable channels and cation channels activated by aluminum in the apical cells of wheat roots. Plant Physiol. 2001, 125, 1459-1472. [CrossRef]

73. Salazar, F.S.; Pandey, S.; Narro, L. Diallel analysis of acid-soil tolerant and intolerant tropical maize populations. Crop Sci. 1997, 37, 1457-1462. [CrossRef]

74. Ascacio-Valdés, J.A.; Buenrostro-Figueroa,J.J.; Aguilera-Carbo, A.; Prado-Barragán, A.; Rodríguez-Herrera, R.; Aguilar, C.N. Ellagitannins: Biosynthesis, biodegradation and biological properties. J. Med. Plants Res. 2011, 5, 4696-4703.

75. Khan, A.; Nazar, S.; Lang, I.; Nawaz, H.; Hussain, M.A. Effect of ellagic acid on growth and physiology of canola (Brassica napus L.) under saline conditions. J. Plant Interact. 2017, 12, 520-525. [CrossRef]

(C) 2020 by the authors. Licensee MDPI, Basel, Switzerland. This article is an open access article distributed under the terms and conditions of the Creative Commons Attribution (CC BY) license (http://creativecommons.org/licenses/by/4.0/). 